\title{
The Rich or the Poor: \\ Who Gains from Public Education Spending in Ghana?
}

\author{
By
}

Mawuli Gaddah

Alistair Munro

October 2011
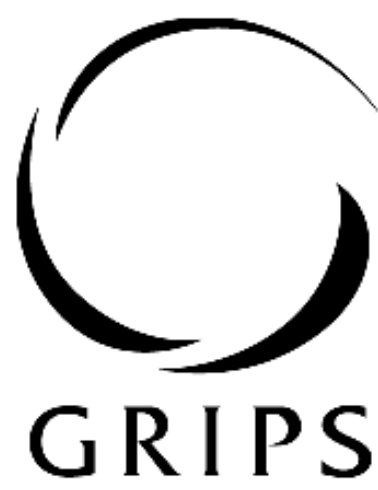

National Graduate institute FOR POLICY STUDIES

National Graduate Institute for Policy Studies

7-22-1 Roppongi, Minato-ku,

Tokyo, Japan 106-8677 


\title{
The Rich or the Poor: Who Gains from Public Education Spending in Ghana?
}

\author{
Mawuli Gaddah* and Alistair Munro \\ National Graduate Institute for Policy Studies (GRIPS) \\ 7-22-1 Roppongi, Minato-ku, Tokyo 106-8677, Japan \\ alistair-munro@grips.ac.jp \\ mawulian2000@yahoo.com
}

\begin{abstract}
This paper examines the incidence of public education subsidies in Ghana. Since the late 1990s, Ghana's government has increasingly recognised human capital as a cornerstone to alleviating poverty and income inequality, causing dramatic increases of government expenditures to the education sector. At the same time user fees have been introduced in higher education while basic education is being made progressively free. The question then is, whether these spending increases have been effective in reaching the poor and to what extent? What factors influence the poor's participation in the public school system? We attempt to address these issues, employing the standard benefit incidence methods and the willingness-to-pay method using a nested multinomial logit model. The results give a clear evidence of progressivity with consistent ordering: preschooling and primary schooling are the most progressive, followed by secondary, and then tertiary. The poorest quintile gains $14.8 \%$ of total education benefits in 2005 compared to the richest quintile benefit of $26.3 \%$. Own price and income elasticities are higher for private schools than public schools and for secondary than basic schools.
\end{abstract}

Keywords: Ghana, public education spending, progressivity, concentration curves, school choice, nested multinomial logit, elasticity, poverty.

\section{JEL Classification Codes: H22, H52, H53}

\section{Introduction}

Human capital development is widely recognized as an important requirement for achieving sustained economic growth and rising incomes, particularly in developing countries (World Bank 1995). Its role was critical in the outstanding economic transformation of Japan, Taiwan, Hong-Kong, South-Korea, and other fast-growing economies (Becker 1995). Empirical evidence suggests that each additional year of schooling is associated with a 6-10 percent increase in earnings in developing countries (Duflo 2001), providing further support for educational investment as an effective approach to poverty reduction both by encouraging economic growth and as a method of redistribution to the poor (Besley and Burgess 2003).

In Ghana, the government has identified investments in human capital (education and health) as an important means of achieving broad-based growth resulting in effective

\footnotetext{
* Corresponding author
} 
poverty reduction (GOG 2005, Canagajah and Ye 2001). ${ }^{1}$ Thus, public education expenditures have increased consistently, reaching about 20 percent of total expenditures (about 5.0 percent of GDP) and 74.0 percent of social spending in 2005 (Osei et al. 2007:10). ${ }^{2}$ The question then is, have those spending increases improved access to, and choice of public schools? What factors determine the choice of education services? Who then are the actual beneficiaries of subsidized education services?

Two general approaches have been widely used to assess the welfare impact of public spending: (1) benefit incidence studies, and (2) behavioural approaches. Previous benefit incidence studies (Demery et al. 1995; Canagarajah and Ye 2001) suggest that, in Ghana, the poorest quintile received about 16 percent of total education subsidies in 1992. Relevant as these studies may still be, their data is nearly 20 years old, suggesting the value of some updated estimates. ${ }^{3}$ Besides, by assigning the same unit costs to all users of public services, the benefit incidence approach assumes that all users benefit equally from public services. Again, the benefits incidence method does not have behavioural foundations and therefore cannot be used for policy simulations. On the other hand, the behavioural approach-also called the willingness-to-pay (WTP) method-has often tended to gloss over the distributional implications of the demand estimates (Younger 1999) and the expenditures financing those public services.

Thus, we use a combination of benefit incidence and behavioural (willingness-to-pay) approaches to analyse the welfare impact of public education expenditures (Younger 1999). We use a nested multinomial logit (NMNL) model to estimate the demand for education services and then use the compensating variations (CVs) derived from those estimates to value education services to households. The demand estimates also enable us to examine the factors influencing households' utilization of these services and to conduct some policy simulations. We also conduct a marginal incidence analysis by comparing our results with Demery et al (1995) to see how education benefits have changed overtime.

The data for this study are drawn from the latest round of the Ghana Living Standards Survey (GLSS5 2005/06). GLSS5 includes a sample of 8,687 households containing 37,128 household members. The survey collected information on individual and households, as well as information on current education level and type of school, employment, income and consumption. Our sample includes all children who are attending school or who are "eligible" to attend school. The latter group includes all children of the appropriate age who have not yet graduated from the level of school under consideration. Public education expenditures as well as unit costs incurred at each education level were obtained from the Ministry of Education Science and Sports (MOESS).

The remainder of the paper proceeds as follows: Section 2 provides a brief overview of the education sector in Ghana. The review of previous research is considered in section 3 while section 4 explains the methodology and presents the results of the benefit

\footnotetext{
${ }^{1}$ Human capital (education and health) has been identified as one of the four main pillars of GPRS II. Prior to this, the vision 2020 document has also paid priority attention to human capital (GOG 1997).

${ }^{2}$ Public social spending has increased consistently during the last decades, reaching over 23 percent of total government expenditures and over 57 percent of discretionary expenditures in 2005 .

${ }^{3}$ This finding was based on 1992 GLSS 3 survey.
} 
incidence of public education subsidies and school choice model. Section 5 presents the concluding remarks and policy implications.

\section{A brief overview of the education system}

Ghana's education system - established initially to reflect a standard British-style education - was once regarded as one of the most developed in Western Africa (Demery et al 1995). The general economic decline of the early 1980s severely affected the education system and by the mid-1980s, the system was already in sharp decline. The education budget as a share of GNP had declined by 5.0 percentage points between 1975 and 1983 (6.4 percent to 1.4 percent) with primary education spending per capita falling by 61 percent over the same period (Demery et al 1995). Besides budgetary issues, the education system also suffered from acute shortage of educational materials including teachers, textbooks, and instructional materials throughout the country's schools (Akyeampong et al 2007). The problem was exacerbated by poor conditions of service (low salaries) which caused the exodus of trained teachers for greener pastures elsewhere, particularly to Nigeria, where the oil boom has increased the demand for professionals including teachers.

Against this background, a radical educational reform was launched in 1987 as part of the overall economic reform program (ERP), which sought, among others, to expand and create a more equitable access at all levels of education; to change the structure of the school system, reducing the length of pre-tertiary education from 17 to 12 years while increasing contact hours between teachers and pupils. ${ }^{4}$ The deteriorations that characterized the sector in the 1970 s were halted while the infrastructure base was improved. The number of basic schools also witnessed a significant increase-rising from 12,997 in 1980 to 18,374 in 2000 - while attendance and completion rates improved (Akyeampong et al., 2007). Total government expenditure on education had more than doubled under the ERP, moving from 1.4 percent of GDP in 1983 to 3.8 percent in 1992 (Demery et al 1995). Total education expenditures (actual) both as a share of the national discretionary budget and GDP have also increased consistently reaching 31.0 percent and 6.0 percent respectively in 2006 (MOES 2008); the lion's share going to basic education.

Financing education has remained central in Ghana's education policy. ${ }^{5}$ Rate of return studies have shown that in Sub-Saharan Africa, both the social and private rate of return are highest in primary education and lowest in higher education (Psacharopoulos [1994]; World Bank [1995]). At the same time, benefit incidence studies have shown that public expenditures on primary education are welfare improving compared to those on higher education. The implication of these findings is straight forward: 1) cut subsidies to higher education and introduce cost recovery through user fees, 2) raise subsidies to basic education and abolish tuition fees. In the mid-1990s and consistent with the above policy implications, Ghana's education system witnessed two main policy reforms: cost recovery measures were introduced in higher education to be achieved through increased school fees, facilities user fees, and withdrawal of subsidies while 'free and compulsory

\footnotetext{
${ }^{4}$ The reforms have replaced the four-year middle schools with a three-year junior secondary, and reduces senior secondary from 7 years - 5 years ordinary level and 2 years advanced level — to 3 years. Primary and junior secondary have become basic education.

${ }_{5}^{5}$ The central government remains the main financier of education, contributing about 82.0 percent (including the GETFUND) of total education spending between 2003 and 2008.
} 
universal basic education' (FCUBE) was introduced in basic education (to be achieved by 2005).

The cost recovery measure was initially opposed by tertiary education students with demonstrations and disruption of academic calendars, forcing fees to remain consistently low with little upward adjustments. The new policy is to allow qualified applicants who do not get a place in the regular admission but can afford the full fees to enrol. The FCUBE initially covered only the tuition fee. However, the cost of sending a child to school goes far beyond tuition. Other costs such as cost of uniform, books, travel, tariffs for structural works, parent' teacher association fees-used as supplements to the government subsidies to the schools (Canagarajah and Ye 2001) - all impose substantial burden on households (Aryeetey and Goldstein, 2000). The program led to steady but slower increase in school enrolments, yet failed to reduce the opportunity cost of schooling to households (Akyeampong 2009). In order to make the FCUBE fully operational, the government, in 2005, initiated the capitation grant concept, abolishing fees being charged in basic schools by providing each school with a little grant for each child enrolled. ${ }^{6}$ The school lunch and the free uniform programmes have also been launched.

The recent proliferation of private universities also marked a significant feature of the reforms. These institutions, mainly religious based, offer a limited number of professional courses-accountancy, marketing, economics, banking and finance, and computer science - tailored towards the labour market. They target mainly working class students and run programmes in the evenings and on part-time bases, employing mostly part-time teachers. They derived revenue from tuition and boarding fees (Larocque 2001). The traditional universities have come under constant attacks from employers in recent years for failing to produce graduates that meet the changing labour market standards. Thus, the emergence of the private institutions should be seen as a welcome development since they are more focused on the job market requirements than just providing a general education.

\section{Public spending, education and poverty}

The impact of public spending on educational outcome has been a major subject of research for years, with mixed results. The general consensus is that public spending alone is insufficient for achieving improved educational outcomes of the poor. The issue of targeting is equally important (Martinez-Vazquez 2001). Meanwhile, Yuki (2003) has compiled studies that examined the incidence of public spending on education in a crosssection of developing countries. For those that focus on Africa, the poorest quintile shares in total education subsidies were $16.4 \%$ in Ghana in 1992 (21.8\% primary, $14.9 \%$ secondary, $6.0 \%$ tertiary), $19.9 \%$ in South Africa in 1993 (25.8\% primary, $18.8 \%$ secondary, $6.1 \%$ higher), $19.4 \%$ in Cote d'Ivoire in 1995 (28.8\% primary, $11.2 \%$ secondary), $17.0 \%$ in Kenya in 1992 (21.8\% primary, 6.4\% secondary, 2.0\% higher), $16.0 \%$ in Malawi in 1995 (20.0\% primary, 9.0\% secondary, $1.0 \%$ higher), $13.0 \%$ in Tanzania in 1994 (20.0\% primary, 7.6\% secondary, 0.0\% higher), 8.3\% in Madagascar in

\footnotetext{
${ }^{6}$ The programme was first piloted in 40 most deprived districts in 2004 . Gross enrolment shot up by 14.5 percent while that of pre-school was 38 percent. Given its success, the programme was adopted nationally in 2005 , which offers GH $\notin 2.5$ per boy child and GHф3.5 per girl child to cover school fees and levies such as cultural dues, sports dues, and development levies.
} 
1994 (17.2\% primary, $2.0 \%$ secondary, $0.0 \%$ higher). In all these countries, the poor gains a disproportionately higher proportion of primary schools subsidies while subsidies to higher education accrue mainly to the wealthy.

More specific evidence can be found in Glick and Razakamanantsoa (2005) who find in Madagascar that primary and secondary education are more equally distributed than consumption expenditures. University enrolments are however, concentrated among the wealthy than consumption. Primary schooling was found to be per capita progressive while secondary and university schooling were found to be per capita regressive - they accrue disproportionately to the well off. Younger (1999) also uses a combination of benefit incidence and behavioural approaches to assess the relative progressivity of public services in Ecuador in 1994 and finds that primary education is the most progressive, followed by secondary education, public universities and then private universities. He actually compared three different versions of the benefit incidence method: standard (with unit cost which varies by region), uniform (binary indicator: one if a service is used and zero otherwise), and compensating variation-based and concludes that the three methods yield similar results in terms of the ranking of public services with consistent ordering. In a related study in Peru in 1998, Younger (2000) finds that, spending on primary education is the most progressive, followed by secondary schooling, then post-secondary. He also observed that though social spending is likely to have an equalizing redistributional effect, its overall impact on poverty was only marginal. Glick and Sahn (2006) find in Madagascar that fee increases reduce public and total (public plus private) primary enrolment proportionately much more for the poor than the well-off, making the distribution of schooling less equitable. They also find that improvement in public school quality tends to benefit the poor disproportionately.

\section{Estimation}

\subsection{Benefit incidence and welfare dominance}

Benefit incidence has become a fairly standard first line method of assessing the impact of public expenditures. One key issue is the degree of progressivity in benefits, usually depicted via concentration curves. The concentration curve is a normative tool similar to the Lorenz curve, and plots the cumulative shares of individuals in the population, ranked by household expenditure per capita/per equivalent adults on the $\mathrm{x}$ axis and the cumulative shares of benefits on the y-axis. However, unlike the Lorenz curve, which represents the cumulative percentage of total income held by a cumulative proportion of the population (after ordering income in increasing magnitude), a concentration curve can lie above the diagonal-the poorest $40 \%$ of the population cannot earn more than $40 \%$ of total income, but they can receive more than $40 \%$ of total benefits from public spending (Hakro and Akram [2007]). 


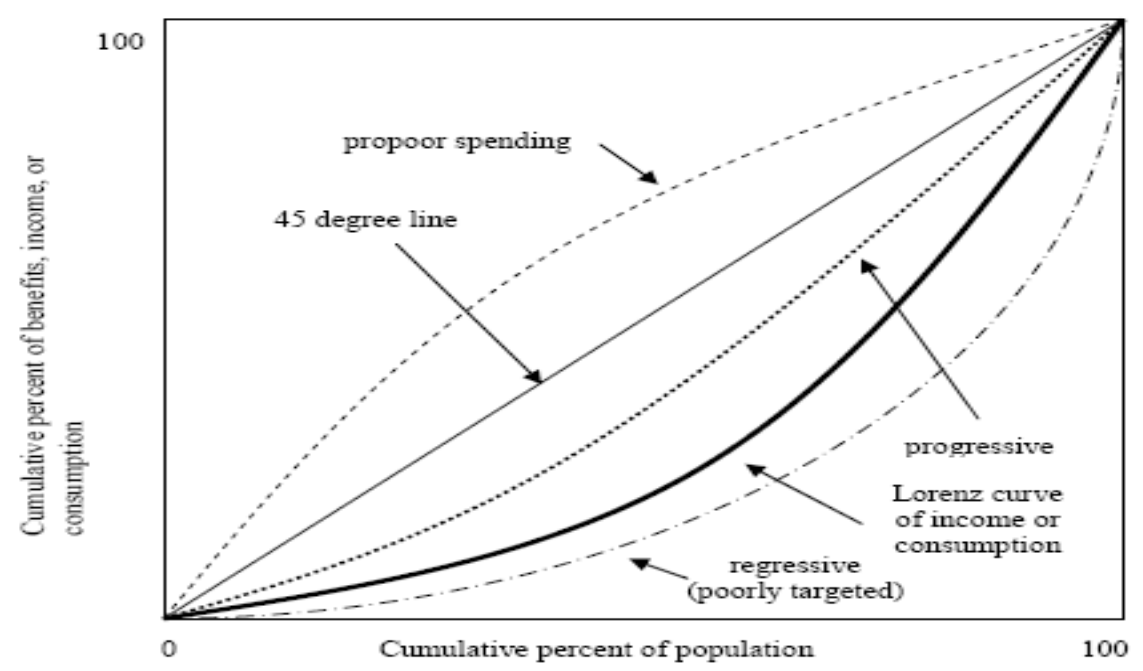

Source: Hakro and Akram (2007)

Figure 1: Lorenz and Concentration Curves

Two measures of progressivity can be defined (Younger et al., 1999; Glick and Razakamanantsoa, 2005). 'Expenditure progressivity', or simply progressivity, involves comparing the distribution of the benefit to the distribution of welfare (expenditures). If the benefit concentration curve dominates the expenditure Lorenz curve- that is, if it is at all points above the curve for household expenditures - then the benefit is said to be progressive. Such a benefit would more likely redistribute the resources even if funded by proportional taxes, and the poorer are comparatively better off when considering both their income and public spending, compared to considering only their income (Hakro and Akram [2007]).

The second measure is called 'per capita progressivity' following Sahn and Younger (2000). This compares the distribution of the benefit to the distribution of the population rather than expenditures. Here, a benefit is said to be per capita progressive (pro-poor) if the benefit curve lies everywhere above (dominates) the 45 degree line. Benefits whose concentration curves lie everywhere above the diagonal show that poorer households receive disproportionately large shares of the benefit. This measure is relatively stricter but insures that, for any definition of the poverty line, the poor receive a disproportionate share of the benefit. Concentration curves that lie below the Lorenz curve are classified as regressive - the benefit accrues disproportionately to the wealthy. 
It is also possible to rank different services according to their progressivity. For example, a given subsidy is said to dominate another if its concentration curve is everywhere above the concentration curve for the other. The concentration coefficient, which is calculated in the same fashion as the GINI coefficient, estimates the inequalities in the distribution of government expenditures. The difference however, is that the concentration coefficient is calculated by keeping the income group the same (Hakro and Akram [2007]). The concentration coefficient can lie in range of -1 and 1 while the GINI coefficient lies between 0 and 1 . If the concentration coefficient is lower than the GINI coefficient, it shows that expenditures are more evenly distributed than income and vice versa.

\section{The distribution of education benefits for the poor}

We begin by estimating the incidence of public education expenditures for all levels of education (primary, secondary and post-secondary). Note that benefit incidence and progressivity analyses refer to public services only. Subsidies refer to recurrent expenditures on each level of education. Figure 2 presents the concentration curves for the various education services considered. Each graph shows two concentrations curves - distribution of children and the benefit concentration curves. We first evaluate these curves against our benchmarks of Lorenz curve (household consumption expenditure) and the perfect equality line (45-degree line). One can easily tell which of these services is progressive. The fact that the concentration curves for children dominate the 45-degree line indicates that there are more children in the poorest quintile than in the richest quintile. For instance, 20.8 percent of school-age children $(3-23$ years $)$ are found in the poorest quintile ( 25.5 percent for poorer households) compared to about 17.9 percent for the richest quintile (13.0 percent for richer households), thus showing that poorer households tend to have more children.

From figure 2, all education services dominate the Lorenz curve with the exception of tertiary education, indicating that pre-tertiary education services are progressive. Their concentration coefficients are much smaller than the GINI coefficient (Table 3). The poorest quintile's share of total education spending (14.8 percent) is significantly higher than their share of household expenditures (5.1 percent), indicating that public education spending is more equitably distributed than household expenditures (Table 2 ). The richest quintile however received 26.3 percent of total benefits; higher than its distribution of children but much less than its share of total household expenditures. This trend is consistent at all education levels except post-secondary whose benefits to the poorest quintile are much less than their share of income. The curves become sharply more convex with increase in the level of education. For instance, the poorest quintile's share of education benefits declines from about 20 percent for pre-school to 4.0 percent for tertiary education while the richest quintile's share of the benefits increases from 14.6 percent for pre-school to 50.3 percent for post-secondary respectively (Table 2).

Primary (and pre-schooling) schooling benefits are more concentrated among the poorest quintile with the bottom two quintiles receiving a cumulative share of about 41 percent, indicating that primary education subsidies are definitely progressive. The poorest quintile's rate of participation in public primary is higher than that of the richest quintile (79 percent against 70.0 percent) mainly because a large proportion of children in the richest quintile are enrolled in private primary. Secondary and tertiary schooling are 
all dominated by the $45^{0}$ line, hence are said to be per capita regressive. Benefits from these services accrue more disproportionately to the well-off households; hence are poorly targeted. Senior high (including TVET) is progressive in terms of household expenditures with the poorest quintile receiving 15.5 percent of the benefits of this level compared to 26.3 percent for the richest quintile. ${ }^{7}$ Post-secondary (universities, polytechnics, and teacher education) education is regressive in absolute terms (both in terms of household expenditures and the $45^{\circ}$ line) with the richest quintile appropriating 50.3 percent of the benefits (Table 2). Though subsidies to teacher education are more equally distributed than those to universities and polytechnics, its contribution seems too small to affect the overall progressivity of post-secondary subsidies.

\section{Distribution across Households and Differences by Gender and Locality}

The above results assessed across individuals show that the distribution of public education benefits does not favour the poor in absolute terms. For instance, while the poorest quintile received 14.8 percent of total benefits, the richest quintile has appropriated 26.3 percent of the benefits. Assessing the distribution across households however gives a different picture in favour of poorer households. For instance, the poorest households received 20.3 percent of total subsidies while the richest households gained 14.9 percent of the benefits, showing a concentration of benefits in poorer households. The poorest households gain more in basic schooling while benefits from post-basic education accrue disproportionately to richer households (Table 2). This gain to poorer households however, falls short of the distribution of its school-age population (25.5 percent for poorest households and 13.2 percent for richest households).

The distribution of benefits also varies by geography (rural/urban) and gender. Rural areas received a disproportionate share of public education benefits, capturing 59.2 percent of total education subsidies in 2005 , which decreases with an increase in the level of education (Table 2). The bulk of basic education benefits accrue disproportionately to rural areas, which received 76.8 percent and 68.0 percent of primary and junior high subsidies respectively (Table 2). As for senior high and tertiary education, urban areas have received the lion's share (58.4 and 74.4 percent respectively).

With regards to gender, males received slightly higher education benefits (51.7 percent) than women (48.3 percent) with much disparity coming from secondary (Table 5). There was almost equal distribution of benefits between males and females for postsecondary, mainly because of teacher education which tend to enrol more female students.

Our next task is to evaluate these services against each other-relative progressivity (Younger 1999). A casual observation of these curves can tell us which services are more progressive. Primary (and pre-school) services are the most progressive since their concentration curves dominate those of all other services, followed by secondary, which in turn is more progressive than post-secondary; a pattern that has become standard for developing countries (Glick and Razakamanantsoa 2005). ${ }^{8}$ The analysis of school

\footnotetext{
${ }^{7}$ Junior high and senior high (including TVET) all dominate the Lorenz curve of household expenditures. Junior high crosses the 45-degree line-the poorest quintile captured 16.2 percent of subsidies to this level compared to 18.9 percent for the richest quintile. For this service, all quintiles received higher benefits than the richest quintile, with the exception of the bottom quintile.

${ }^{8}$ More pointedly, primary is the most progressive, followed by JHS, SHS/TVET, and then post-secondary. Subsidies to TVET/TTC dominate those of SHS. The poorest quintile's share of post-secondary benefits was only about 4.0 percent.
} 
enrolment rates shows that a number of children in poorest households tend to terminate their schooling at primary level, and some at JHS. Thus, the widening gap between primary and secondary education is a reflection of this trend.

Changes in the incidence of education subsidies: 1989 - 2005

How has the incidence of public education spending changed over time? Has targeting improved over the years? Here we consider the change in the benefit incidence of public education spending by comparing the results to Demery et al. (1995). These studies are actually comparable because the databases are similar. The study of Demery at al. (1995) is based on the GLSS 2 (1989) and 3 (1992) while the present study is based on GLSS 5 (2005/06), all of which are nationally representative household surveys conducted by the Ghana Statistical Service (GSS). For the sake of this comparison, we group pre-school and primary into primary education; JHS, SHS, and TVET are grouped into secondary, while universities, polytechnics, and teacher education are grouped into post-secondary. After basic school (JHS), children can either enroll in SHS or TVET. However, SHS is required for tertiary (university and polytechnic) and teacher training. For 2005, the benefit to secondary is a weighted average of JHS and SHS (including TVET). Table 5 reports the changes in distribution of education benefits between 1989 and 2005. The poorest quintile remains the smallest beneficiary of total education benefits, showing a declining share of total benefits between 1989 and 2005. For instance, the share of total benefits accruing to the poorest quintile has declined by 2.3 percentage points; falling from 17.1 percent in 1989 to 14.8 percent in 2005 . It declined by 0.7 percentage point between 1989 and 1992, and further by 2.6 percentage points between 1992 and 2005. The bottom two quintiles accounted for an accumulated share of 32.3 percent of total benefits in 2005 compared with their cumulative income share of about 16 percent. The richest quintile however, appropriated 26.3 percent of total education benefits in 2005, gaining by 5.5 percentage points between 1992 and 2005 and 2.6 percentage points over the period 1989-2005 (Table 5). The bottom two quintiles witnessed a decrease in primary education benefits over the period 1992 and 2005, with benefits decreasing by 3.4 and 1.4 percent respectively over this period.

After primary education, benefits accrue disproportionately to the richest quintile. For instance, the poorest quintile received 14.9 percent of secondary ${ }^{9}$ education benefits in 1992 and 16.0 percent in 2005, indicating an increase of 1.1 percentage points. The richest quintile on the other hand has gained by 6.3 percentage points over this period (rising from 18.6 percent in 1992 to 24.9 percent in 2005). The poorest quintile continues to make a generally poor showing in tertiary education compared with the richest quintile (4.0 percent against 50.3 percent). Between 1992 and 2005, the poorest quintile's share of tertiary education benefits has declined by 2.0 percentage points while the richest quintile's share has increased by 5.1 percentage points (Table 5). ${ }^{10}$

The share of rural areas in total education subsidies has increased by 1.3 percentage points between 1992 and 2005, with its share of the total benefits remaining consistently high $(58.7,57.9$, and 59.2 percent in 1989, 1992, and 2005 respectively). In terms of education levels, rural areas received 77.1 percent of primary education subsidies in 2005

\footnotetext{
${ }^{9}$ For 2005 , the benefit to secondary is a weighted average of JHS and SHS (including TVET).

${ }^{10}$ Ranking in terms of expenditure per capita, the change in tertiary benefits for the richest quintile was 21 percentage points as against a decline of 5.5 percentage points for the poorest quintile.
} 
(rising by 7.0 percentage points from 70.1 percent in 1992). It also received 60.2 and 25.6 percent of secondary and post-secondary subsidies respectively in 2005. Accra's share of primary education benefits have decreased consistently between 1989 and 2005, with its share in total education subsidies dropping by 5.6 percentage points over this period (Table 5).

\subsection{School choice model}

The benefit incidence analysis presented above lacks behavioural foundation, hence cannot be used for policy simulation. In this section we derive and present results on a school choice model that enables us to understand behavioural responses to public spending. Following previous authors (Gertler, Locay and Sanderson 1987; Gertler and Glewwe 1990; Younger 1999; and Glick and Sahn 2001), we assume that households derive utility from the human capital of children, which depends on schooling and on the consumption of all other goods (net income). Confronted with the decision to enrol in public school, private school, and non-enrolment, parents choose the option that yields the highest utility. Schooling raises the human capital, a kind of asset to parents which is achieved at the cost of school fees and reduced consumption of other goods. An individual will only choose the non-enrolment/no-school option only if it yields utility higher than all other alternatives. For each option (say option j), the indirect utility associated with choosing that option depends on the following simple linear specification:

$$
V_{i j}=c\left(Y_{i}-P_{i j}\right)+\beta_{1} S_{i j}+e_{i j}
$$

Where, $\mathrm{c}\left(\mathrm{Y}-\mathrm{P}_{\mathrm{j}}\right)$ is net household income (proxied by household expenditure, $\mathrm{Y}$ ) less school cost at option $\mathrm{j}\left(\mathrm{P}_{\mathrm{ij}}\right)$, which includes both the direct and the indirect (opportunity) costs. Finally, $e_{j}$ is a noise term specific to the household and unobserved by the researcher, which can be correlated across options within a branch. The function $\mathrm{S}_{i j}$, which represents the increase in human capital, is expected to vary across options since the quality of the alternatives may differ. For the non-enrolment option, $S_{\mathrm{ij}}$ is normalized to zero based on the assumption that the individual gains no utility from not attending school. Since the change cannot be directly observed, $\beta_{1} S_{i j}$ is replaced by a reduced form equation for the utility from human capital as follows:

$$
\beta_{1} S_{i j}=\gamma Q_{j}+\delta_{j} X_{i}+n_{i j}
$$

Where $Q_{j}$ is a vector of school quality variables and $X_{i}$ is a vector of observed household and individual characteristics. This is what Glick and Sahn (2001) referred to as representing a production function of human capital in which both school and household variables are inputs. Substituting (3.4) into (3.3) yields

$$
V_{i j}=c\left(Y_{i}-P_{i j}\right)+\gamma Q_{j}+\delta_{j} X_{i}+\varepsilon_{i j}
$$

Where, $\varepsilon_{\mathrm{ij}}=\mathrm{e}_{\mathrm{ij}}+\mathrm{n}_{\mathrm{ij}}$ and $\delta_{\mathrm{j}}$, the coefficient on household and individual characteristics are allowed to be constant across alternatives. We assume the function, $S_{i j}$ to be linear while net income is assumed to be logarithmic - i.e. $c\left(Y_{i}-P_{i j}\right)=a \log \left(Y_{i}-P_{i j}\right) .^{11}$

\footnotetext{
${ }^{11}$ An issue is the functional form for net income, $\mathrm{c}\left(\mathrm{Y}_{\mathrm{i}}-\mathrm{P}_{\mathrm{j}}\right)$, for which there is no consensus in the literature. Previous authors have used various specifications: linear (Akin 1985; Dor and van der Gaag 1993); quadratic (Gertler and van der Gaag 1990; Gertler and Glewwe 1990); logarithmic Younger (1999; 2000).
} 
The specification used in this study is a NMNL model with three options for school choice considered-no-school/non-enrolment, public, or private. The NMNL model allows us to relax the homoscedasticity (independence of irrelevant alternatives (IIA)) assumption of a potential conditional logit model. ${ }^{12}$ In this framework, since the decision to choose a particular provider is a discrete choice problem, the determination of demand involves estimating the probability that a particular service provider-public or private-will be chosen. In this model, two of the options are in one nest while the other option (with utility normalized to zero) is in the second nest. Thus, the probability that a person chooses provider $\mathrm{j}$ is given as (3.6):

$$
\pi_{j}=\frac{\exp \left(V_{j} / \sigma\right)\left(\sum_{k} \exp \left(V_{k} / \sigma\right)\right)^{\sigma-1}}{1+\left(\sum_{k} \exp \left(V_{k} / \sigma\right)\right)^{\sigma}}, \mathrm{k}=\mathrm{j}, \mathrm{i}
$$

As we noted, the cost of schooling $\left(\mathrm{P}_{\mathrm{j}}\right)$ includes both the direct and the indirect (opportunity) cost. The GLSS 5 survey which forms the database for this study defines the direct cost as the sum of registration and tuition fee, cost of uniforms, cost of books, transport cost, parent teacher association dues, feeding and boarding, and expenses on extra classes. Opportunity cost measures the cost of the time needed to stay in school (Younger 1999), and it is calculated for children aged 10 or older as the time spent at school (6 hours) plus travel time multiplied by a predicted wage estimated from a simple OLS wage function (Table A.1). For children below this age, we assume a zero opportunity cost.

For the options not chosen, because we do not have figures for direct costs and travel time, we estimate them using the median observed cost for the child's region, area (rural/urban), and type of school (public/private). The use of median scores is to avoid the extreme values bias often associated with mean scores. For the no-school option, the net income is just the gross income..

The national survey does not contain quality information; hence the $S_{i j}$ is simply a function of household and individual characteristics plus an option specific dummy. By leaving out important quality variables that probably correlate with net income and with the probability of choosing a particular provider could mean that we are overestimating elasticity estimates which could tend to underestimate the incidence of the education services (Younger 1999). However, in Younger (1999) this omitted variable does not affect the progressivity of services.

We considered three samples for our demand function estimations: pre-school, primary, and secondary. We did not include tertiary education in the demand function estimates for two reasons: rationing of tertiary education and the share of the private sector was too small. Our sample includes all children who are attending school or who are "eligible" to attend school. The latter group includes all children of the appropriate age who have not yet graduated from the level of school under consideration. We follow the standard practice and include all children of an appropriate age who have already graduated from the previous level (at least 3 for pre-school, at least 6 for primary, at least

\footnotetext{
${ }^{12}$ The nested logit reduces to the conditional logit if the two dissimilarity parameters are both equal to 1 (Cameron and Trivedi, 2009).
} 
15 for secondary, at least 18 for tertiary). In order to account for late entry and overage attendance - a typical phenomenon in Ghana - we truncate the sample at a maximum age ( 8 for pre-school, 14 for primary, and 21 for secondary). ${ }^{13}$ Given that those who have already graduated from the current level do not have demand for that level, we omit children of an appropriate age who have already graduated this level. Each model includes similar regressors of age, gender, relationship with head of household, net income, years completed at the current level, head's education and age, a dummy of household composition (number of men, number of women, number of children) while controlling for religion, area of residence, and sector of employment (Table A.3).

Table 6 presents the means and standard deviations of these variables. From the Table, net household expenditure differs from gross expenditure by the total school cost. The indirect cost (opportunity cost) constitutes the lion's share of total cost, representing 55 percent of total school cost in both primary and secondary samples. These costs are slightly higher for private providers than the public provider. The means of net income and their standard deviations were $\not 17.9$ million and $\varnothing 15.9$ million respectively for the pre-school sample, 20.1 and 19.7 for the primary sample, 23.4 and 26.4 respectively for secondary sample (GLSS 5). These figures also vary across options. For instance, within the pre-school sample, mean net income is 14.7 for the no-school option, 18.1 for the public school option, and 28.1 for the private school option. The mean ages for the various samples are 4.9 for pre-school, 9.5 for primary, and 18.1 for secondary. Females constitute more than 48.0 percent of each sample. Majority of households (over 70.0 percent) dwell in rural areas with over 20 percent headed by women (Table 6).

\section{Econometrics results}

Table 7 presents estimates of the NMNL model of school choice for pre-school, primary, and secondary schooling. For each model, the Wald tests reject the null of all coefficients being zero and the null of equality of coefficients across the public and private options. Due to the nature of our nested structure, we have to constrain the noschool option to unity; hence its dissimilarity parameter is 1 . The dissimilarity parameters, $\sigma(0.88$ for pre-primary, 0.26 for primary, and 0.24 for secondary) are between zero and one, indicating that our model is consistent with the additive random utility maximization. The LR tests, $\tau$ rejects the IIA assumption and give strong support for the NMNL instead of a MNL model.

The coefficient for net income, the variable of interest is positive and significant in all equations. As for the child's characteristics, we find that age increases the probability of enrolling in both pre-school and primary school (both public and private) but turns negative for secondary. Being the child of the household's head positively and significant increases the probability of enrolments, both public and private. Despites the slight gender difference in school attendance reported earlier, the gender indicator $(=1$ if female) is not statistically significant at any conventional significant levels, except in the secondary equation where females have a lower probability of enrolment. The number of years previously completed at the current level has a positive and significant effect on the

\footnotetext{
${ }^{13}$ For secondary school, some authors include even children of secondary age who have not yet graduated from primary school (Younger 1999). Secondary includes only senior high.
} 
probability of enrolment at all levels. ${ }^{14}$ Years of schooling of the household's head positively and significantly increases the probability of a child's school attendance both across samples and equations, with the exception of the secondary model.

The age of the household head is not significant at all conventional significant levels, with the exception of the public pre-school equation. A female headed household has a higher probability of enrolment in all models, exception secondary. Number of men, number of women, and number of children negatively and significantly decrease the probability of private pre-school enrolments at 1.0 percent significant level. They are insignificant in both primary and secondary equations. We also controlled for regional and religious differences, as well as the sector of employment of the head of the household; only significant variables are reported (Table 7).

\section{Valuation based on the compensating variation}

The analyses presented in section 4.1 are based on the standard benefit incidence (unit-cost) approach which is often criticised for its arbitrary valuation of public services. ${ }^{15}$ The alternative is to use measures benefits estimated from the school choice model. Compensating variation $(\mathrm{CV})$ is that amount of money that when subtracted from the individual's income in the new state (1) makes utility in the new state, with the subtraction, equal to utility in the original state (0). That is,

$$
V=c\left(Y_{i}-P_{j}^{1}\right)++\gamma Q_{j}+\delta_{j} X_{i}+\varepsilon_{j}^{1}=c\left(Y_{i}-P_{j}^{0}-C V\right)+\gamma Q_{j}+\delta_{j} X_{i}+\varepsilon_{j}^{0}
$$

where, $\mathrm{P}^{0}$ is price in the original state, $\mathrm{P}^{1}$ is price in the new state etc. In the method developed by Morey and Rossman (2007), it is supposed that the household-specific epsilon terms are the same in both states and therefore cancel by assumption. We use the NMNL estimates presented above to calculate CV for public schooling, which we then used to assess the benefits of public schooling to households.

Specifically, for a household where public schooling is the best option and private schooling provides the second highest level of utility, CV is defined implicitly by the following equation,

$$
C V=\left(Y-P^{0}\right)-e^{\left(\frac{\left.V_{\text {private }}-V_{\text {public }}\right)}{\alpha}\right)}\left(Y-P^{1}\right)
$$

where $\mathrm{V}_{\text {public }}$ and $\mathrm{V}_{\text {private }}$ are the estimated utilities associated with public and private options respectively, $\alpha$ is the coefficient of net income. In the case where the second best

\footnotetext{
${ }^{14}$ This is what Younger (1999) called the "sheepskin effect", which shows the fact that: 1) returns to schooling is not simply the accumulation of human capital (which suffers from diminishing marginal return); rather it signals achievement by the completion of a level and the reward of a particular degree; 2) one is more likely to attend a good school for several years than a bad one, reflecting the unobserved quality differences in schools.

${ }^{15}$ For instance, by assigning the same unit cost to all observed users, the standard approach is assuming that all households benefits equally from public services. In practice however, children from poorer households are more likely to attend poorer quality schools compared to children from wealthier homes.
} 
option for a household is no schooling then we replace $\mathrm{V}_{\text {private }}$ by 0 . Where the best option is either no schooling or private schooling, then $\mathrm{CV}=0$.

Figure 3 compares the three different methods - standard, uniform, and the CV-based methods-while the dominance tests are reported in Table 10. For the services considered, our finding agrees largely with Younger (1999) that the method of valuation does not affect the ranking of social services. Services that are (per capita or expenditure) progressive with one method is in most cases so with other methods. What is however unclear, is the order of progressivity. For both pre-school and primary schooling, the standard method is obviously the most progressive, followed by the uniform and then the compensating variation. For secondary schooling (only senior high) however, the test could not confirm dominance of any one method over another (Table 10).

\section{The elasticity of demand}

The coefficients of the NMNL estimates can be difficult to interpret, thus we explore the influence of price and income variables by the analysis of elasticities. If we let $\mathrm{p}_{\mathrm{j}}$ to represent the price for provider $\mathrm{j}$, which by assumption only enters utility of option $\mathrm{j}\left(\mathrm{V}_{\mathrm{j}}\right)$, then it follows that

$$
\frac{\partial \pi_{j}}{\partial p_{j}}=\pi_{j} \frac{\partial V_{j}}{\partial p_{j}} \frac{1}{\sigma}\left[1+\frac{(\sigma-1) \exp \left(V_{j} / \sigma\right)}{\sum_{i} \exp \left(V_{i} / \sigma\right)}-\frac{\sigma \exp \left(V_{i} / \sigma\right)\left(\sum_{k} \exp \left(V_{k} / \sigma\right)\right)^{\sigma-1}}{1+\left(\sum_{k} \exp \left(V_{k} / \sigma\right)\right)^{\sigma}}\right], \mathrm{k}=\mathrm{j}, \mathrm{i}
$$

Hence, the own elasticity,

$$
\varepsilon_{j j}=\frac{\partial V_{j}}{\partial p_{j}} \frac{p_{j}}{\sigma}\left[1-\sigma \pi_{j}+\frac{(\sigma-1) \exp \left(V_{j} / \sigma\right)}{\sum_{k} \exp \left(V_{k} / \sigma\right)}\right]
$$

Note that this equals the standard formula for multinomial logit when sigma is 1 . Note also that $\left(\frac{\partial V_{j}}{\partial p_{j}}\right)=-\frac{\alpha}{y-p_{j}}=-\frac{a}{\text { Net expenditur } e_{j}}$ where, $\alpha$ is the coefficient on net household expenditure.

The elasticity estimates: Table 8 reports price and income elasticities of demand calculated at mean levels for each schooling option by expenditure quintile. As would be expected, the price elasticities are consistently negative in all equations and options. For all income quintiles, the elasticities are significantly higher (in absolute terms) for private providers than the public provider. Demand for schooling becomes more elastic as one move from primary to secondary. For instance, a 1.0 percent increase in direct cost of schooling (including tuition, textbooks and supplies) would result in a reduction in demand for public pre-schools by 0.033 percent among the poorest quintile as compared to 0.043 percent in private pre-school, other factors being constant. A similar pattern is observed for primary and secondary schooling, though with higher elasticities (Table 8). 
All income elasticities also have the expected positive sign, with the lower income groups exhibiting higher price and income elasticities. That is, demand for schooling among the lowest income individuals is substantially more price and income elastic than among the richest group. This suggests that income, proxied by household expenditure is a crucial determinant of school enrolment and school choice. A one percent increase in income would lead to about 0.125 percentage point increase in the demand for private secondary schools as compared with 0.05 percentage point increase in public secondary schools among the poorest income group (Table 8).

Policy simulation: We complement the above elasticities of demand by carrying out a number of policy simulations. Making education, especially public education more accessible to the people may involve one or more of the following: 1) making public schools free, 2) offering subsidies that make private schools free, and 3) increasing the income of poorer households. We do not have information to calculate the relative cost of these policies but at least we can simulate the impact of each in a simple way. The procedure followed here is, first, we set public provider's price to zero and simulate the change in predicted probability on both the three options (no-school, private and public). Second, we set private providers' price to zero. Third, we increase the income of the poorest households (details below) and simulate its effect on predicted probability. These predicted probabilities are then compared with the predicted probabilities for our baseline model.

Table 9 reports the results of the simulations for the three samples (pre-school, primary, and secondary respectively). From the baseline model (when all variables are at their actual values), we find that, 32.2 percent of the pre-school sample, 62.5 percent of the primary sample, and 21.4 percent of the secondary sample will choose public school. A larger proportion however $(48.2,19.8$, and 74.6 percent respectively) will stay out of school (Table 9). When we set the public provider's price to zero, we find that, the probability of attending public schools rose to 51.5, 73.1, and 26.5 percent for pre-school, primary, and secondary schools respectively, while the probability of choosing the private option declines significantly, indicating a substitution into public option. Making private provider's price equal to zero also resulted in a massive substitution into private schooling (Table 9), but compared to the first simulation has a smaller impact on the probability of not attending a school.

The fact that non-enrolment is still high even after setting prices to zero is a reflection of the negative effect of high opportunity costs on schooling demand. Akyeampong (2009) highlighted the inability of the FCUBE to reduce the indirect cost of schooling as a major issue with the programme.

In our next simulation, we move all households in the poorest quintile into the second quintile, and then move all poor households to the upper poverty line set by the Ghana Statistical Service (GSS 2007). We find no drastic change in probabilities. The marginal changes in the probabilities due to changes in income of the poorest households are however, consistent with the low income elasticities (not reported). This could be suggesting that merely moving households to the poverty line is not particularly effective 
in increasing attendance; income must be raised well above the poverty line in order to make significant impacts on school attendance. ${ }^{16}$

\section{Conclusion and policy implications}

In this paper, we have presented a description of the distribution of public education expenditures, coverage, utilization as well as the benefit incidence of public education spending in Ghana, considering all levels of education-pre-schooling, primary, secondary, and tertiary. We find that the education system, particularly public education is generally progressive-benefits are more equally distributed than household expenditures but not in absolute terms. The poorest quintile received 14.8 percent of total education subsidies in 2005, greater than its share of household expenditures. In relative terms, primary schooling is the most progressive, followed by secondary, then postsecondary; an ordering that has become standard for developing countries. Secondary education is also fairly progressive (relative to household expenditure but not in absolute terms) while tertiary education is regressive in absolute terms (both in terms of the Lorenz curve and the $45^{\circ}$ line). A high proportion of school-age children are terminating their schooling at primary and many more at junior high.

The demand estimates show that price and income are important determinants of school enrolments. The fact that the poor's demand for schooling is more price-elastic than the wealthy suggests that price increases for public schooling will have negative implications for equity. Increases in cost will result in a larger than proportionate reduction in demand among the poor compared with the wealthy, making the distribution of public primary school benefits less progressive. From our policy simulations, though setting prices to zero led to dramatic increases in school enrolment, the high probability of non-attendance reflects the high opportunity cost to schooling.

Our finding suggests that: 1) a basic education subsidy applied uniformly across the income distribution will disproportionately benefit the schooling of poor children; 2) if the government gave all households an annual income transfer, rather than subsidized education, income expenditure distribution would improve, other things being constant; 3 ) and because we considered average instead of marginal incidence, we can cautiously say that, an additional cedi spent on basic education would more likely improve equity than an additional cedi spent on secondary and tertiary education, if both are spent in the same way as the current budget so that neither the beneficiaries nor their share of the benefits change.

\footnotetext{
${ }^{16}$ A similar trend was observed by moving everybody out of the poorest quintile, which involves awarding the minimum income in the $2^{\text {nd }}$ quintile to all households in the poorest quintile.
} 


\section{References:}

Aaron, H, and Mcguire MC (1970): "Public goods and income distribution", Econometrica 38 (6): 907-920.

Ablo, E. And R. Reinikka (1998): "Do budgets really matter? Evidence from public spending on education and health in Uganda", Policy Research Working Paper 1926, Development economics research group, The World Bank, Washington, D.C.

Akyeampong, K., J. Djangmah, A. Seidu, A. Oduro, and F. Hunt (2007): “Access to Basic Education in Ghana: The Evidence and the Issues". CREATE Country Analytic Review. Winneba/ Brighton: The University of Education at Winneba CIE, University of Sussex.

Akyeampong, Kwame (2009): "Revisiting Free Compulsory Universal Basic Education (FCUBE) in Ghana". Comparative Education, 45 (2): 175-195.

Aryeetey, Ernest and Markus Goldstein (2000): "The Evolution of Social Policy" in 'Economic Reforms: The Miracle and the Mirage', Ernest Aryeetey, Jane Harrigan, and Machiko Nissanke (ed), James Currey and Woeli Publications.

Besley, Timothy and Robin Burgess (2003): "Halving Global Poverty", Journal of Economic Perspective, Vol. 17, No. 3. Pp 3-22.

Becker, Gary (1995): "Human Capital and Poverty Alleviation", Human Resources Development and Operations Policy, HRO Working Papers, HROWP 52

Bidani, Benu, and Martin Ravallion (1997): "Decomposing Social Indicators Using Distributional Data", Journal of Econometrics 77: 125 - 39

Cameron, Colin, A., and Pravin K. Trivedi (2009): "Microeconometrics Using Stata", Publisher: Stata Press | ISBN: 1597180483 | edition 2009 |

Canagarajah, Sudharshan and Xiao Ye (2001) "Public Health and Education Spending in Ghana in 1992-98: Issues of Equity and Efficiency". Social Science Research Network, Working Paper Series

Demery, Lionel (2000): "Benefit incidence: A practitioner's Guide". Poverty and Social Development Group, Africa Region, The World Bank.

Demery, Lionel, Shiyan Chao, Rene Bernier and Kalpana Mehra (1995): "The Incidence of Social Spending in Ghana". PSP Discussion Papers Series No. 82, Poverty and Social Policy Department, The World Bank.

Duclos, Jean-Yves, Abdelkrim Araar and Carl Fortin, 2006, "DAD: a software for Distributive Analysis / Analyse Distributive", MIMAP programme, International Development Research Centre, Government of Canada, and CIRPÉE, Université Laval.

Duclos, Jean-Yves and Abdelkrim Araar (2006): "Poverty and Equity: Measurement, Policy, and Estimation with DAD”, Springer 233 Spring Street, NY 10013

Duflo, Esther (2001): "Schooling and Labour Market Consequences of School Construction in Indonesia: Evidence from an Unusual Policy Experiment", American Economic Review 91(4), 795-813

Gertler, Paul, Luis Locay, and Warren Sanderson (1987): “Are User Fees Regressive The Welfare Implications of Health Care Financing in Peru". Journal of Econometrics 33:67-88 
Gertler, Paul, and Paul Glewwe (1990): "The Willingness to Pay for Education in Developing Countries: Evidence from Rural Peru", Journal of Public Economics 42: 251-275, North-Holland

Ghana Statistical Service (2007): "Pattern and Trends of Poverty in Ghana: 1991-2006".

Ghana Statistical Service (2008): "Ghana Living Standards Survey Report of the Fifth Round (GLSS 5).

Glick, Peter and David Sahn (2001) 'The Demand for Primary Schooling in Madagascar: Price, Quality, and the Choice between Public and Private Providers over the 1990s:http://siteresources.worldbank.org/INTPSIA/Resources/490023$1120845825946 /$

Glick, Peter and Mamisoa Razakamanantsoa (2005): "The Distribution of Education and Health Services in Madagascar over the 1990s: Increasing Progressivity in an Era of Low Growth". Journal of African Economies 15: 399-433.

Government of Ghana (GOG), 2005: "Growth and Poverty Reduction Strategy (GPRS II) (2006 - 2009), National Development Planning Commission.

Government of Ghana/Ministry of Education (GOG/MOE). 1996. "Free Compulsory Universal Basic Education (FCUBE)", Accra: Ministry of Education.

Hakro, Ahmed Nawaz, and Muhammed Akram (2007): "The Incidence of Government Expenditures on Education and Health: Microeconomic Evidence from Pakistan”, The Lahore Journal of Economics, 12 (2): 27 - 48

Harbison, R., and Eric Hanushek (1992): "Educational Performance of the Poor: Lessons from Rural Northeast Brazil", Oxford University Press

Larocque, N. (2001): "Private education in Ghana: A market and regulatory survey". A paper prepared for the World Bank Group, Wellington, New Zealand.

Martinez-Vazquez, Jorge (2001): "The Impact of Budgets on the Poor: Tax and Benefit", International Studies Program Working Paper Series, at AYSPS, GSU no.0110

Mckay, Andrew (2002): "Assessing the Impact of Fiscal Policy on Poverty". Discussion Paper No. 2002/43, WIDER

Meerman, Jacob (1979): "Public Expenditure in Malaysia: Who Benefits and Why?" The World Bank, Oxford University Press, New York.

Mingat, A., Tan, J. (1992): "Education in Asia: A Comparative Study of Cost and Financing", World Bank, Human Development Department, Education Group, Washington, D.C.

Mingat, A., Tan, J. (1998): "The Mechanics of Progress in Education: Evidence from Cross-country Data", Policy research working paper 2015, Human Development Department, Education Group, World Bank, Washington, D.C.

Ministry of Education Science and Sports (MOESS). Education Sector Performance Report. Various issues.

Morey, Edward and Kathleen Greer Rossmann (2008): "Calculating, With Income Effects, the Compensating Variation for a State Change". Environmental and Resource Economics, 39: 83-90

Nishimura, Makiko and Takahashi Yamano (2008): "School Choice between Public and Private Primary Schools under the Free Primary education Policy in Rural Kenya". GRIPS Policy Information Centre, Discussion Paper No. 08-02.

O’Donnell, Owen, Eddy van Doorslaer, Adam Wagstaff, and Magnus Lindelow (2008): "Analysing Health Equity Using Household Survey Data: A Guide to Techniques 
and Their Implementation", WBI Learning Resources Series, The World Bank 1818 H Street, $N W$

Osei, Robert Darko, Isaac Osei-Akoto, William Quarmine and George Adayi-Nwoa Adiah (2007): "Public Spending in Ghana: An Assessment of National Level Data (1995 - 2005)". Ghana Strategy Support Program (GSSP) Background paper No. GSSP 0004.

Palmer, Robert (2007): "Education, Training and Labour Market Outcomes in Ghana: A Review of the Evidence", RECOUP Working Paper No. 9 WP07/09

Pascharropolous, G., 1994, "Returns to Investment in Education: a Global Update", World Development 22, pp $1325-1343$.

Rajkumar, Andrew S. And Vinaya Swaroop (2002): "Public Spending and Outcomes: Does Government Matter?" World Bank Policy Research Working Paper No. 2840.

Sackey, Harry A. (2007): "The Determinants of School Attendance and Attainment in Ghana: A Gender Perspective", AERC Research Paper 173, African Economic Research Consortium, Nairobi

Sahn, D. and Stephen, Y. (2000): "Expenditure incidence in Africa: microeconomic evidence", Fiscal Studies, Vol. 21, pp. 329-347

Sandy, Janathan (1989): "The Choice of Public or Private School", The Social Science Journal, 26 (4): 415-431.

Schwartz, Gerd, and Teresa Ter-Minassian (2000): "The Distributional Effects of Public Expenditure", Journal of Economic Surveys 14 (3)

Selowsky, Marcelo (1979): "Who Benefits from Government Expenditures? A Case Study of Colombia", Oxford University Press, New York, 1979.

UNESCO (2007): "Education for All by 2015: Will we make it?", Global Monitoring Report. Paris: UNESCO

Van de Walle, Dominique (1998) "Assessing the Welfare Impact of Public Spending", World Development, 26 (3): 365-379.

Wedgwood, Ruth (2005): "Education and Poverty Reduction in Tanzania", hakielimu Working Paper 9

World Bank (1990) 'World Development Report 1990. New York: Oxford University Press.

World Bank (1995): "Priorities and Strategies for Education". A World Bank Review, Washington D.C.

World Bank (1999): "Education sector strategy". Washington DC, The World Bank

World Bank (1995): "Ghana: Poverty Past, Present and Future". Report No. 14504-GH, Washington D.C.

Younger, Stephen (1999): "The Relative Progressivity of Social Services in Ecuador", Public Finance Review, 27(3): 310-352.

Younger, Stephen (2000): "Public Social Sector Expenditure and Poverty in Peru: Evidence from Household Surveys, Http://www.grade.org.pe/eventos/lacea/programa/p24-syounger.PDF.

Yuki, Takako (2003): "Distribution of Public Education Spending for the Poor: The Case of Yemen". Asian Pacific Education Review 4(2): 129 - 139. 
Table 1: Public school enrolments, recurrent expenditure, and unit cost, 2005

\begin{tabular}{|c|c|c|c|c|c|}
\hline \multirow[t]{2}{*}{ Level } & \multirow[t]{2}{*}{ Enrolment } & \multirow{2}{*}{$\frac{\text { Recurrent exp }}{\mathrm{GH} \phi}$} & \multicolumn{3}{|c|}{ Unit $\operatorname{costs}^{\mathrm{a}}$} \\
\hline & & & $\mathrm{GH} \phi$ & US\$ & $\%$ GNI per capita \\
\hline Preschool & 866,678 & $23,282,600$ & 26.9 & 24.4 & 5.2 \\
\hline Primary & $2,727,044$ & $176,628,700$ & 64.8 & 59.0 & 12.6 \\
\hline JHS & 951,673 & $118,188,095$ & 124.2 & 113.0 & 24.2 \\
\hline SHS & 367,242 & $122,687,132$ & 334.1 & 304.0 & 65.0 \\
\hline TVET & 20,303 & $5,339,437$ & 263.0 & 239.3 & 51.2 \\
\hline Teacher & 8,965 & $25,543,000$ & $2,849.2$ & $2,592.8$ & 554.4 \\
\hline Tertiary & 111,893 & $118,353,536$ & $1,057.7$ & 962.5 & 205.8 \\
\hline
\end{tabular}

Source: Preliminary Education Sector Performance Report, 2009

Note: ${ }^{a}$ Exchange rate (US $\$ 1=\mathrm{GH} \not 0.91$ in 2005$)$, GNI per capita (US\$467.7 in 2005):

World Statistics Pocket book, UN Statistics Division, Website. 
Table 2: Benefit incidence of public education expenditures, 2005

\begin{tabular}{|c|c|c|c|c|c|c|}
\hline & \multicolumn{5}{|c|}{ Quintile (\%) } & \multirow[t]{2}{*}{ Total } \\
\hline & 1 & 2 & 3 & 4 & 5 & \\
\hline \multicolumn{7}{|l|}{ Individual Quintiles } \\
\hline Share of school-age population (3-23) & 20.8 & 21.0 & 20.5 & 19.8 & 17.9 & 100 \\
\hline Share of basic school-age population (6-14) & 22.0 & 21.9 & 21.1 & 19.4 & 15.6 & 100 \\
\hline Female share of sample & 46.3 & 49.0 & 50.0 & 51.3 & 54.8 & 50.3 \\
\hline Rural share of sample & 91.0 & 83.6 & 69.5 & 51.8 & 27.3 & 64.6 \\
\hline Share of household expenditure & 5.1 & 10.1 & 15.1 & 22.6 & 47.1 & 100 \\
\hline \multicolumn{7}{|c|}{ Rate of participation by individual quintiles } \\
\hline Rate of participation for pre-school & 46.3 & 61.5 & 68.5 & 67.7 & 41.9 & 57.2 \\
\hline Rate of participation for primary school & 79.0 & 95.8 & 88.7 & 91.3 & 70.3 & 85.0 \\
\hline Rate of participation for JHS & 45.7 & 57.5 & 62.0 & 63.9 & 53.7 & 56.6 \\
\hline Rate of participation for SHS \& TVET & 21.8 & 21.2 & 17.8 & 30.5 & 46.5 & 27.6 \\
\hline Rate of participation for post-secondary & 0.5 & 0.8 & 2.4 & 3.0 & 6.9 & 2.7 \\
\hline \multicolumn{7}{|c|}{ Proportion of education subsidies received by individual quintiles } \\
\hline Share of total education spending & 14.8 & 17.5 & 19.4 & 22.0 & 26.3 & 100.0 \\
\hline Share of pre-school spending & 16.7 & 20.8 & 25.0 & 22.9 & 14.6 & 100.0 \\
\hline Share of primary school spending & 18.6 & 22.4 & 20.8 & 21.4 & 16.5 & 100.0 \\
\hline Share of JHS spending & 16.2 & 20.2 & 21.9 & 22.8 & 18.9 & 100.0 \\
\hline Share of SHS (\& TVET) spending & 15.6 & 15.6 & 19.4 & 22.0 & 26.3 & 100.0 \\
\hline Share of post-secondary spending & 4.0 & 5.5 & 17.6 & 22.2 & 50.3 & 100.0 \\
\hline \multicolumn{7}{|l|}{ Household Quintiles } \\
\hline Share of school-age population (3-23) & 25.5 & 24.0 & 20.0 & 17.3 & 13.2 & 100 \\
\hline Share of basic school-age population (6-14) & 26.6 & 24.2 & 20.7 & 16.7 & 11.8 & 100 \\
\hline Share of total education spending & 20.3 & 21.3 & 21.6 & 18.2 & 18.6 & 100 \\
\hline Share of pre-school spending & 31.3 & 27.1 & 20.7 & 14.6 & 6.3 & 100 \\
\hline Share of primary school spending & 29.7 & 27.6 & 21.6 & 13.8 & 7.3 & 100 \\
\hline Share of JHS spending & 22.8 & 25.0 & 23.2 & 18.9 & 10.1 & 100 \\
\hline Share of SHS (\& TVET) spending & 9.8 & 17.0 & 20.9 & 27.5 & 24.8 & 100 \\
\hline Share of post-secondary spending & 4.5 & 7.4 & 20.8 & 19.7 & 47.6 & 100 \\
\hline
\end{tabular}

Source: Own estimations based on Table 1 and GLSS5 survey. Household are ranked by household expenditure per equivalent adults. 
Table 3: GINI and concentration indices for use of public schooling

\begin{tabular}{lrcrr}
\hline & Estimate & $\begin{array}{c}\text { Standard } \\
\text { error }\end{array}$ & $\begin{array}{r}\text { Lower } \\
\text { bound }\end{array}$ & $\begin{array}{c}\text { Upper } \\
\text { Bound }\end{array}$ \\
\hline Expenditure & 0.417 & 0.002530 & 0.411985 & 0.421903 \\
Subsidy to Pre-school & -0.197 & 0.006785 & -0.209944 & -0.183347 \\
Subsidy to Primary school & -0.200 & 0.004296 & -0.208410 & -0.191567 \\
Subsidy to Junior high school & -0.098 & 0.007084 & -0.112023 & -0.084251 \\
Subsidy to Senior high school & 0.076 & 0.011161 & 0.054016 & 0.097767 \\
Subsidy to Tertiary & 0.433 & 0.019458 & 0.394990 & 0.471267 \\
\hline
\end{tabular}

Source: Authors' estimation based on GLSS 5 data. 
Table 4: Dominance table for education services, standard method only

\begin{tabular}{|c|c|c|c|c|c|c|c|c|c|c|}
\hline & & $(1)$ & $(2)$ & (3) & (4) & (5) & (6) & (7) & (8) & (9) \\
\hline 1). & Pre-school & & $X$ & $D$ & $D$ & $D$ & $D$ & $D$ & $D$ & $D$ \\
\hline 2). & Primary School & $X$ & & $D$ & $D$ & $D$ & $D$ & $D$ & $D$ & $D$ \\
\hline 3). & Junior High School & & & & $X$ & $X$ & $D$ & $D$ & $D$ & $D$ \\
\hline 4). & 45-degree & & & & & $D$ & $X$ & $D$ & $D$ & $D$ \\
\hline 5). & All education & & & & & & $D$ & $D$ & $D$ & $D$ \\
\hline 6$)$. & Others* & & & & & & & $D$ & $D$ & $D$ \\
\hline 7). & Senior High School & & & & & & & & $D$ & $D$ \\
\hline 8). & Expenditure & & & & & & & & & $D$ \\
\hline 9). & Tertiary & & & & & & & & & \\
\hline
\end{tabular}


Table 5: Distribution of public education subsidies: 1989 -2005

\begin{tabular}{|c|c|c|c|c|c|c|}
\hline & \multicolumn{3}{|c|}{$\%$ of benefits received } & \multicolumn{3}{|c|}{ change in benefits } \\
\hline & 1989 & 1992 & 2005 & 1989-92 & 1992-05 & 1989-05 \\
\hline Quintile & \multicolumn{6}{|c|}{ Primary } \\
\hline 1 & 21.2 & 21.8 & 18.4 & 0.6 & -3.4 & -2.8 \\
\hline 2 & 22.1 & 23.6 & 22.2 & 1.5 & -1.4 & 0.1 \\
\hline 3 & 22.2 & 21.7 & 21.3 & -0.5 & -0.4 & -0.9 \\
\hline 4 & 20.3 & 18.8 & 21.5 & -1.5 & 2.7 & 1.2 \\
\hline 5 & 14.3 & 14.0 & 16.3 & -0.3 & 2.3 & 2.0 \\
\hline total, of which & 100 & 100 & 100 & 0.0 & 0.0 & 0.0 \\
\hline Accra & 6.3 & 5.3 & 2.9 & -1.0 & -2.4 & -3.4 \\
\hline Other-urban & 23.1 & 24.6 & 20.3 & 1.5 & -4.3 & -2.8 \\
\hline Rural & 70.6 & 70.1 & 76.8 & -0.5 & 6.7 & 6.2 \\
\hline Quintile & \multicolumn{6}{|c|}{ Secondary } \\
\hline 1 & 16.8 & 14.9 & 16.0 & -1.9 & 1.1 & -0.8 \\
\hline 2 & 18.0 & 21.8 & 18.3 & 3.8 & -3.5 & 0.3 \\
\hline 3 & 21.8 & 21.1 & 18.3 & -0.7 & -2.8 & -3.5 \\
\hline 4 & 23.4 & 23.5 & 22.5 & 0.1 & -1.0 & -0.9 \\
\hline 5 & 19.9 & 18.6 & 24.9 & -1.3 & 6.3 & 5.0 \\
\hline total, of which & 100 & 100 & 100 & 0.0 & 0.0 & 0.0 \\
\hline \multirow{2}{*}{$\begin{array}{l}\text { Accra } \\
\text { Other-urban }\end{array}$} & 11.1 & 12.0 & 8.9 & 0.9 & -3.1 & -2.2 \\
\hline & 23.3 & 30.1 & 30.9 & 6.8 & 0.8 & 7.6 \\
\hline Rural & 65.6 & 57.8 & 60.2 & -7.8 & 2.4 & -5.4 \\
\hline Quintile & \multicolumn{6}{|c|}{ Tertiary } \\
\hline 1 & 7.7 & 6.0 & 4.0 & -1.7 & -2.0 & -3.7 \\
\hline 2 & 3.8 & 9.5 & 5.5 & 5.7 & -4.0 & 1.7 \\
\hline 3 & 19.2 & 19.0 & 17.6 & -0.2 & -1.4 & -1.6 \\
\hline 4 & 19.2 & 20.2 & 22.2 & 1.0 & 2.0 & 3.0 \\
\hline 5 & 50.0 & 45.2 & 50.3 & -4.8 & 5.1 & 0.3 \\
\hline total, of which & 100 & 100 & 100.0 & 0.0 & 0.0 & 0.0 \\
\hline Accra & 42.3 & 27.4 & 27.1 & -14.9 & -0.3 & -15.2 \\
\hline Other-urban & 34.6 & 47.6 & 47.2 & 13.0 & -0.4 & 12.6 \\
\hline Rural & 23.1 & 25.0 & 25.6 & 1.9 & 0.6 & 2.5 \\
\hline Quintile & \multicolumn{3}{|c|}{ All education } & & & \\
\hline 1 & 17.1 & 16.4 & 14.8 & -0.7 & -1.6 & -2.3 \\
\hline 2 & 17.0 & 20.7 & 17.5 & 3.7 & -3.2 & 0.5 \\
\hline 3 & 21.4 & 21.0 & 19.4 & -0.4 & -1.6 & -2.0 \\
\hline 4 & 20.8 & 21.1 & 22.0 & 0.3 & 0.9 & 1.2 \\
\hline 5 & 23.7 & 20.8 & 26.3 & -2.9 & 5.5 & 2.6 \\
\hline total, of which & 100.0 & 100.0 & 100 & 0.0 & 0.0 & 0.0 \\
\hline Accra & 15.6 & 11.6 & 10.0 & -4.0 & -1.6 & -5.6 \\
\hline Other-urban & 25.7 & 30.5 & 29.6 & 4.8 & -0.9 & 3.9 \\
\hline Rural & 58.7 & 57.9 & 59.2 & -0.8 & 1.3 & 0.5 \\
\hline
\end{tabular}

Note: 1989, 1992 (estimated by Demery et al., 1995), 2005 (author's own estimations). 1989 is ranked by household expenditure per capita, 1992 and 2005 are ranked by household expenditure per adults equivalent. 
Table 6: Descriptive statistics of regressors

\begin{tabular}{|c|c|c|c|c|c|c|}
\hline \multirow[t]{2}{*}{ Variable } & \multicolumn{2}{|c|}{ Pre-school } & \multicolumn{2}{|c|}{ Primary } & \multicolumn{2}{|c|}{ Secondary } \\
\hline & Mean & SD & Mean & SD & Mean & SD \\
\hline Age of child & 4.88 & 1.53 & 9.51 & 2.50 & 18.11 & 1.86 \\
\hline Gender $($ female $=1)$ & 0.49 & 0.50 & 0.48 & 0.50 & 0.52 & 0.50 \\
\hline Child of household head & 0.81 & 0.39 & 0.77 & 0.42 & 0.67 & 0.47 \\
\hline Years completed & 0.00 & 0.00 & 3.73 & 1.89 & 1.97 & 0.74 \\
\hline Household head's years & 6.44 & 7.65 & 7.23 & 8.28 & 8.42 & 9.07 \\
\hline Household head's age & 44.16 & 13.06 & 47.55 & 12.74 & 48.26 & 14.20 \\
\hline Gender of head $($ female $=1)$ & 0.19 & 0.39 & 0.22 & 0.42 & 0.25 & 0.43 \\
\hline Number of men & 1.23 & 0.98 & 1.30 & 1.05 & 1.80 & 1.26 \\
\hline Number of women & 1.56 & 0.99 & 1.63 & 1.08 & 2.03 & 1.26 \\
\hline Number of children & 3.96 & 2.26 & 3.95 & 2.26 & 2.66 & 2.33 \\
\hline Head works in formal sector & 0.08 & 0.27 & 0.10 & 0.29 & 0.15 & 0.36 \\
\hline Head works in informal sector & 0.84 & 0.36 & 0.82 & 0.38 & 0.78 & 0.41 \\
\hline Catholic & 0.15 & 0.36 & 0.16 & 0.37 & 0.17 & 0.38 \\
\hline Moslem & 0.21 & 0.41 & 0.20 & 0.40 & 0.20 & 0.40 \\
\hline Traditional religion & 0.11 & 0.32 & 0.10 & 0.30 & 0.09 & 0.28 \\
\hline Resides in Accra (GAMA) & 0.05 & 0.22 & 0.06 & 0.24 & 0.11 & 0.32 \\
\hline Resides in other urban & 0.20 & 0.40 & 0.23 & 0.42 & 0.29 & 0.45 \\
\hline Resides in Rural coastal & 0.08 & 0.27 & 0.09 & 0.29 & 0.06 & 0.24 \\
\hline Resides in Rural forest & 0.27 & 0.44 & 0.26 & 0.44 & 0.20 & 0.40 \\
\hline Resides in Rural Savannah & 0.41 & 0.49 & 0.35 & 0.48 & 0.34 & 0.47 \\
\hline Net income (GHф '000') & 1.79 & 1.59 & 2.01 & 1.20 & 2.34 & 2.64 \\
\hline Travel time (hrs) & 4.35 & 3.12 & 4.37 & 3.15 & 4.30 & 3.05 \\
\hline
\end{tabular}

Source: Authors' estimates based on GLSS 5 surveys 
Table 7: Nested Multinomial Logit estimates for choice of schooling.

\begin{tabular}{|c|c|c|c|c|c|c|}
\hline \multirow[b]{2}{*}{ VARIABLES } & \multicolumn{2}{|c|}{ Pre-school } & \multicolumn{2}{|c|}{ Primary } & \multicolumn{2}{|c|}{ Secondary } \\
\hline & Private & Public & Private & Public & Private & Public \\
\hline \multirow[t]{2}{*}{ Constant } & $2.61 * *$ & 1.30 & $19.25 * * *$ & $19.15 * * *$ & $-7.73 * *$ & $-7.87 * * *$ \\
\hline & $(1.28)$ & $(1.22)$ & $(2.59)$ & $(2.55)$ & $(3.01)$ & $(3.01)$ \\
\hline \multirow[t]{2}{*}{ Age } & $0.42 * * *$ & $0.48 * * *$ & $0.95 * * *$ & $0.91 * * *$ & $-0.76^{* * *}$ & $-0.76 * * *$ \\
\hline & $(0.04)$ & $(0.03)$ & $(0.09)$ & $(0.09)$ & $(0.12)$ & $(0.12)$ \\
\hline \multirow[t]{2}{*}{ Child of head } & 0.08 & 0.14 & $0.58 * * *$ & $0.51 * * *$ & $0.36 * * *$ & $0.35 * * *$ \\
\hline & $(0.17)$ & $(0.12)$ & $(0.11)$ & $(0.11)$ & $(0.12)$ & $(0.12)$ \\
\hline \multirow[t]{2}{*}{ Gender $($ female $=1)$} & 0.10 & 0.12 & 0.03 & 0.01 & $-0.42 * * *$ & $-0.43 * * *$ \\
\hline & $(0.11)$ & $(0.08)$ & $(0.09)$ & $(0.08)$ & $(0.12)$ & $(0.12)$ \\
\hline \multirow[t]{2}{*}{ Years completed } & & & $0.27 * * *$ & $0.32 * * *$ & $1.75 * * *$ & $1.77 * * *$ \\
\hline & & & $(0.09)$ & $(0.09)$ & $(0.14)$ & $(0.14)$ \\
\hline \multirow{2}{*}{ Head years } & $0.07 * * *$ & $0.08 * * *$ & $0.06 * * *$ & $0.06^{* * *}$ & -0.01 & -0.01 \\
\hline & $(0.01)$ & $(0.01)$ & $(0.01)$ & $(0.01)$ & $(0.01)$ & $(0.01)$ \\
\hline \multirow[t]{2}{*}{ Head's age } & -0.01 & $0.01 *$ & -0.00 & 0.00 & 0.01 & 0.01 \\
\hline & $(0.01)$ & $(0.00)$ & $(0.00)$ & $(0.00)$ & $(0.00)$ & $(0.00)$ \\
\hline \multirow[t]{2}{*}{ Female headed } & $0.60 * * *$ & $0.81 * * *$ & $0.59 * * *$ & $0.59 * * *$ & -0.01 & -0.00 \\
\hline & $(0.16)$ & $(0.13)$ & $(0.13)$ & $(0.13)$ & $(0.12)$ & $(0.12)$ \\
\hline \multirow[t]{2}{*}{ Number of men } & $-0.22 * * *$ & -0.06 & -0.07 & -0.06 & 0.02 & 0.02 \\
\hline & $(0.07)$ & $(0.05)$ & $(0.05)$ & $(0.05)$ & $(0.05)$ & $(0.05)$ \\
\hline \multirow{2}{*}{ Number of women } & $-0.18 * *$ & -0.04 & 0.05 & 0.05 & 0.06 & 0.06 \\
\hline & $(0.07)$ & $(0.05)$ & $(0.05)$ & $(0.05)$ & $(0.05)$ & $(0.05)$ \\
\hline \multirow[t]{2}{*}{ Number of children } & $-0.26 * * *$ & -0.02 & -0.01 & 0.02 & 0.04 & 0.03 \\
\hline & $(0.04)$ & $(0.02)$ & $(0.02)$ & $(0.02)$ & $(0.03)$ & $(0.03)$ \\
\hline \multirow[t]{2}{*}{ Head, informal } & & & -0.22 & -0.20 & $-0.47 * * *$ & $-0.47 * * *$ \\
\hline & & & $(0.19)$ & $(0.19)$ & $(0.17)$ & $(0.17)$ \\
\hline \multirow[t]{2}{*}{ Traditional } & $-3.70 * *$ & $-0.98 * * *$ & $-0.70 * * *$ & $-0.59 * * *$ & $-12.20 * * *$ & 0.49 \\
\hline & $(1.67)$ & $(0.18)$ & $(0.16)$ & $(0.14)$ & $(3.40)$ & $(0.46)$ \\
\hline \multirow[t]{2}{*}{ Accra (GAMA) } & $3.82 * * *$ & $1.23 * * *$ & $0.93 * * *$ & $0.55 * *$ & $-0.87 * * *$ & $-0.92 * * *$ \\
\hline & $(0.30)$ & $(0.31)$ & $(0.35)$ & $(0.28)$ & $(0.22)$ & $(0.22)$ \\
\hline \multirow[t]{2}{*}{ Rural coastal } & $1.55 * * *$ & $0.59 * * *$ & 0.28 & $0.29 *$ & $-0.67 * * *$ & $-0.67 * * *$ \\
\hline & $(0.26)$ & $(0.16)$ & $(0.18)$ & $(0.17)$ & $(0.23)$ & $(0.23)$ \\
\hline \multirow[t]{2}{*}{ Rural forest } & $1.58 * * *$ & $0.91 * * *$ & $1.07 * * *$ & $1.06 * * *$ & $-0.69 * * *$ & $-0.72 * * *$ \\
\hline & $(0.22)$ & $(0.12)$ & $(0.14)$ & $(0.14)$ & $(0.19)$ & $(0.19)$ \\
\hline \multirow[t]{2}{*}{ Log(Net expenditure) } & $5.50 * * *$ & $5.50 * * *$ & $3.94 * * *$ & $3.94 * * *$ & $3.24 * * *$ & $3.24 * * *$ \\
\hline & $(1.56)$ & $(1.56)$ & $(1.35)$ & $(1.35)$ & $(1.26)$ & $(1.26)$ \\
\hline \multirow[t]{2}{*}{$\sigma$} & $0.88 * * *$ & $0.88 * * *$ & $0.26 * * *$ & $0.26 * * *$ & $0.24 * * *$ & $0.24 * * *$ \\
\hline & $(0.24)$ & $(0.24)$ & $(0.09)$ & $(0.09)$ & $(0.02)$ & $(0.02)$ \\
\hline$\tau$ & $15.28 * * *$ & $15.28 * * *$ & $52.48 * * *$ & $52.48 * * *$ & $7.06 * * *$ & $7.06 * * *$ \\
\hline Loglikelihood & -3062.69 & -3062.69 & -4628.60 & -4628.60 & -1666.99 & -1666.99 \\
\hline$\%$ correctly predicted & 75.2 & 75.2 & 86.7 & 86.7 & 79.3 & 79.3 \\
\hline Observations & 4047 & 4047 & 8234 & 8234 & 2632 & 2632 \\
\hline
\end{tabular}

Base category is No-school, Standard errors in parentheses $* * * \mathrm{p}<0.01, * * \mathrm{p}<0.05, * \mathrm{p}<0.1$

Source: Own Calculations based on GLSS 2005/06 
Table 8: Price and income elasticity of education demand

\begin{tabular}{|c|c|c|c|c|c|c|}
\hline & \multicolumn{3}{|c|}{ Own price elasticity } & \multicolumn{3}{|c|}{ Income elasticity } \\
\hline & Preschool & Primary & Secondary & Preschool & Primary & Secondary \\
\hline \multicolumn{7}{|l|}{ Private } \\
\hline Poorest quintile & -0.043 & -1.551 & -4.149 & 0.048 & 0.124 & 0.125 \\
\hline 2 & -0.022 & -0.542 & -1.345 & 0.035 & 0.089 & 0.101 \\
\hline 3 & -0.016 & -0.378 & -0.917 & 0.031 & 0.076 & 0.093 \\
\hline 4 & -0.012 & -0.301 & -0.646 & 0.028 & 0.065 & 0.086 \\
\hline Richest quintile & -0.009 & -0.192 & -0.393 & 0.024 & 0.048 & 0.082 \\
\hline \multicolumn{7}{|l|}{ Public } \\
\hline Poorest quintile & 0.033 & -0.147 & -0.850 & 0.012 & 0.521 & 0.005 \\
\hline 2 & -0.008 & -0.096 & -0.369 & 0.010 & 0.041 & 0.048 \\
\hline 3 & -0.011 & -0.123 & -0.491 & 0.011 & 0.043 & 0.050 \\
\hline 4 & -0.008 & -0.131 & -0.443 & 0.013 & 0.048 & 0.048 \\
\hline Richest quintile & -0.007 & -0.124 & -0.433 & 0.015 & 0.057 & 0.051 \\
\hline
\end{tabular}

Source: Own estimations based on Table 7. 
Table 9: Simulated probabilities by expenditure quintiles, and type of provider

\begin{tabular}{cccccccc}
\hline & \multicolumn{3}{c}{ Predicted probabilities } & & \multicolumn{3}{c}{ Change in probabilities } \\
\cline { 2 - 3 } \cline { 6 - 8 } Pre-school & Primary & Senior & & Pre-school & Primary & Senior \\
\hline Baseline probabilities & & & & & & \\
None & 0.4816 & 0.1983 & 0.7459 & & 0.0 & 0.0 & 0.0 \\
Private & 0.1801 & 0.1773 & 0.043 & & 0.0 & 0.0 & 0.0 \\
Public & 0.3383 & 0.6245 & 0.2135 & & 0.0 & 0.0 & 0.0 \\
Price of public option is zero & & & & & & \\
None & 0.3663 & 0.1694 & 0.7065 & & -0.1153 & -0.0289 & -0.0394 \\
Private & 0.1184 & 0.0794 & 0.0088 & & -0.0617 & -0.0979 & -0.0342 \\
Public & 0.5153 & 0.7511 & 0.2848 & & 0.1770 & 0.1266 & 0.0713 \\
Price of private option is zero & & & & & & \\
None & 0.3864 & 0.1721 & 0.7142 & & -0.0952 & -0.0262 & -0.0317 \\
Private & 0.4345 & 0.49 & 0.1352 & & 0.2544 & 0.3127 & 0.0922 \\
Public & 0.1791 & 0.3378 & 0.1505 & & -0.1592 & -0.2867 & -0.063 \\
Moving everybody out of poorest quintile & & & & & \\
None & 0.481 & 0.1975 & 0.741 & & -0.0006 & -0.0008 & -0.0049 \\
Private & 0.1964 & 0.1778 & 0.0452 & & 0.0163 & 0.0005 & 0.0022 \\
Public & 0.3226 & 0.6247 & 0.2137 & & -0.0157 & 0.0002 & 0.0002 \\
Moving poor households to the poverty line & & & & & \\
None & 0.4814 & 0.1977 & 0.7390 & & -0.0002 & -0.0006 & -0.0069 \\
Private & 0.1956 & 0.1777 & 0.0470 & & 0.0155 & 0.0004 & 0.0040 \\
Public & 0.323 & 0.6246 & 0.2140 & -0.0153 & 0.0001 & 0.0005 \\
\hline \hline
\end{tabular}

Source: Own estimation based on Table 10 
Table 10: Dominance Table for education services, various methods

\begin{tabular}{|c|c|c|c|c|c|c|c|c|c|}
\hline & $(1)$ & $(2)$ & (3) & $(4)$ & (5) & (6) & $(7)$ & $(8)$ & (9) \\
\hline 1. Pre-school, standard & & $D$ & $D$ & $X$ & $D$ & $D$ & $D$ & $D$ & $D$ \\
\hline 2. Pre-school, uniform & & & $D$ & $D$ & $D$ & $D$ & $D$ & $D$ & $D$ \\
\hline 3. Pre-school, CV & & & & $D$ & $D$ & $D$ & $D$ & $D$ & $D$ \\
\hline 4. Primary, standard & $X$ & & & & $D$ & $X$ & $D$ & $D$ & $D$ \\
\hline 5. Primary, uniform & & & & & & $X$ & $D$ & $D$ & $D$ \\
\hline 6. Primary, $C V$ & & & & & & & $D$ & $D$ & $D$ \\
\hline 7. Secondary, standard & & & & & & & & non- $D$ & non- $D$ \\
\hline 8. Secondary, uniform & & & & & & & & & non-D \\
\hline 9. Secondary, CV & & & & & & & & & \\
\hline
\end{tabular}

Note: $\mathrm{D}$ indicates that the row dominates the column. $\mathrm{X}$ indicates that the curves cross, and 'non-D' indicates non dominance. 
Table A1: Variables definition

NETEXPEND (in million C)

Years completed

Head Years

Number of men

Number of women

Number of Children

Female

Child of head

Other Child

Female headed

Catholic

Pentecostal

Moslem

Traditional

Accra (GAMA)

Other urban

Rural coastal

Rural forest

Rural savanna

Head formal sector

Head informal sector
Household expenditure minus schooling cost

Number of school years completed by the child

Number of schooling years by child's father

Number of men aged 18-60 years

Number of men aged 18-60 years

Number of children aged $<15$ years

Dummy variable ( $=1$ if child is male, 0 if female)

Dummy variable ( $=1$ if child of head, 0 otherwise)

Dummy variable ( $=1$ if not child of, 0 other household member)

Dummy variable ( $=1$ household head is female, 0 if male)

Dummy variable ( $=1$ if child is a Catholic, 0 otherwise)

Dummy variable ( $=1$ if child is a Pentecostal, 0 otherwise)

Dummy variable ( $=1$ if child is a Moslem, 0 otherwise)

Dummy variable ( $=1$ if child is a religion is traditional 0 otherwise)

Dummy variable ( $=1$ if child lives in Accra metropolis, 0 otherwise)

Dummy variable ( $=1$ if child lives in other urban areas, 0 otherwise)

Dummy variable ( $=1$ if child lives in rural coastal area, 0 otherwise)

Dummy variable ( $=1$ if child lives in rural forest area, 0 otherwise)

Dummy variable ( $=1$ if child lives in rural savanna area, 0 otherwise)

Dummy variable (= 1 if head works in a formal area, 0 otherwise)

Dummy variable (= 1 if head works in a informal area, 0 otherwise) 
Appendix A2: OLS Wage model

\begin{tabular}{|c|c|c|}
\hline Variables & Coefficient & T-value \\
\hline Constant & 11.2327 & 115.78 \\
\hline Age & 0.0198 & 8.22 \\
\hline Age square & -0.0005 & -10.09 \\
\hline Married & 0.2003 & 7.02 \\
\hline \multicolumn{3}{|l|}{ Region/area of residence } \\
\hline Accra (GAMA) & 0.9523 & 19.85 \\
\hline Other urban & 0.6569 & 17.39 \\
\hline Rural coastal & 0.3150 & 6.83 \\
\hline Rural forest & 0.3058 & 7.93 \\
\hline \multicolumn{3}{|l|}{ Relationship to head } \\
\hline Spouse of head & -0.3678 & -12.31 \\
\hline Relatives & -0.4313 & -6.08 \\
\hline Non relatives & -0.5935 & -2.61 \\
\hline \multicolumn{3}{|l|}{ Household composition } \\
\hline No. Of relatives in household & -0.0021 & -0.20 \\
\hline No. Of non relatives in household & 0.1414 & 2.88 \\
\hline Number of men in household & 0.0966 & 7.37 \\
\hline Number of women in household & -0.0079 & -0.59 \\
\hline Number of children in household & 0.0161 & 2.28 \\
\hline \multicolumn{3}{|l|}{ Years of education } \\
\hline Primary graduate e & 0.2837 & 9.86 \\
\hline Secondary graduate & 0.6664 & 15.23 \\
\hline University/Polytechnic graduate & 1.2764 & 13.72 \\
\hline Postgraduate & 2.2534 & 11.62 \\
\hline \multicolumn{3}{|l|}{ Father's education } \\
\hline Primary graduate & -0.0797 & -1.24 \\
\hline Middle/Junior high graduate & 0.0122 & 0.37 \\
\hline Secondary graduate & 0.0983 & 1.32 \\
\hline Postsecondary graduate & 0.2383 & 3.52 \\
\hline \multicolumn{3}{|l|}{ Mother's education } \\
\hline Primary graduate & 0.0065 & 0.10 \\
\hline Middle/Junior high graduate & -0.0616 & -1.60 \\
\hline Secondary graduate & -0.0352 & -0.36 \\
\hline Postsecondary graduate & 0.0899 & 0.67 \\
\hline \multicolumn{3}{|l|}{ Head's sector of employment } \\
\hline Formal & 0.3082 & 5.03 \\
\hline Informal & 0.0456 & 0.86 \\
\hline
\end{tabular}

Source: Own estimations based on GLSS 5 data. Note: $\mathrm{N}=9,796$ observations. $\mathrm{R}^{2}=0.235$. Model estimated on all respondents older than 9 years who reported to have worked and received wages. The dependent variable is log wage. 
Figure 2: Concentration Curves for Public schooling, 2005/06

(a) Pre-school, 2005/06

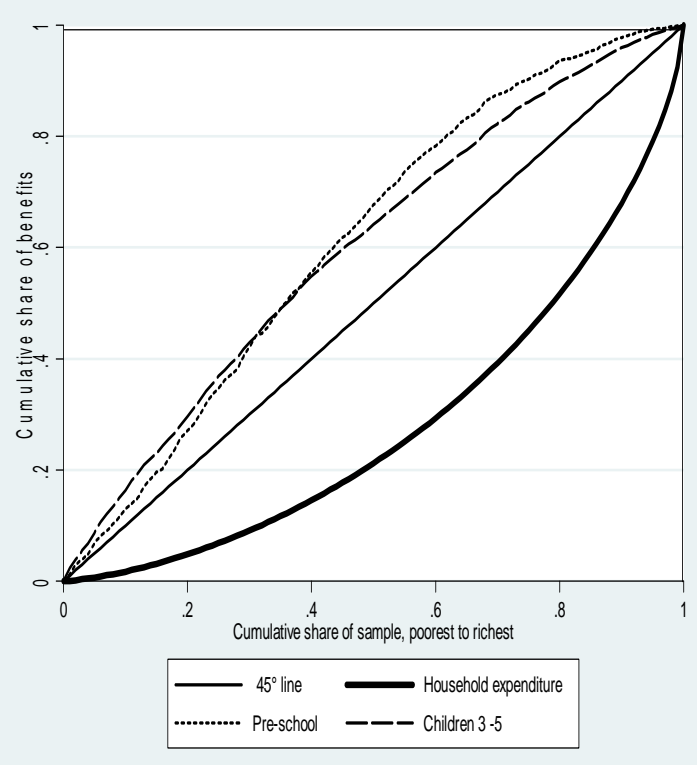

(c) Junior high schooling, 2005/06

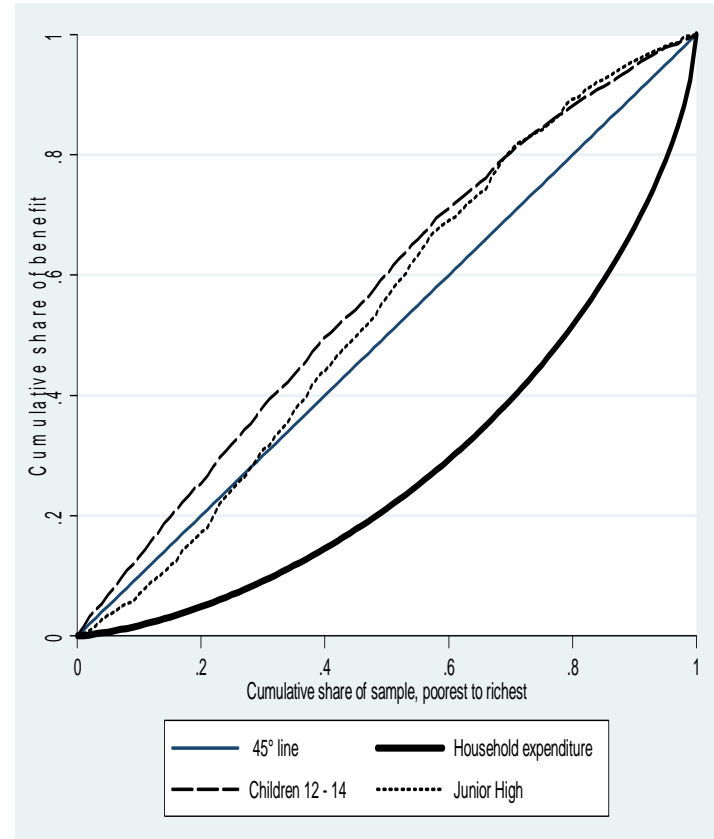

(b) Primary schooling, 2005/06

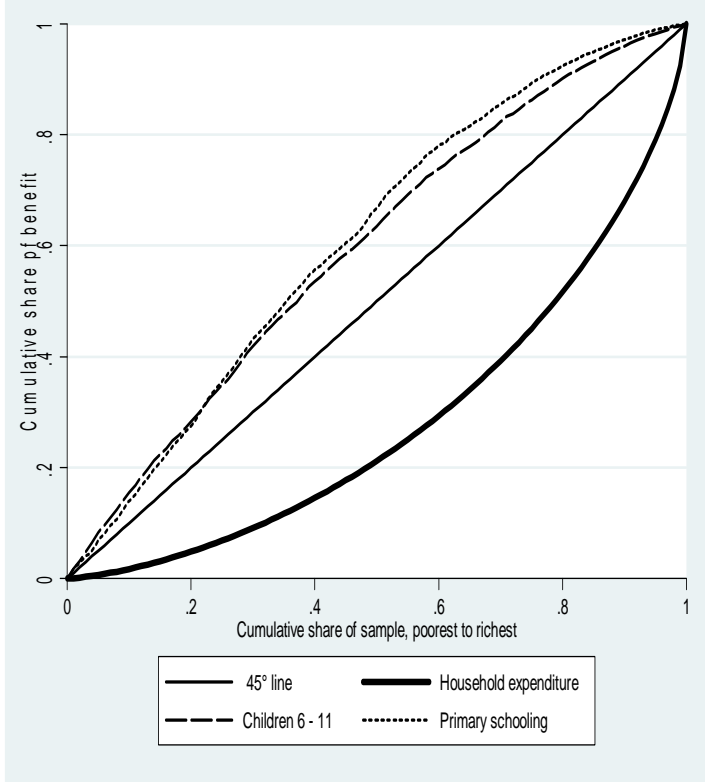

(d) Senior high schooling, 2005/06

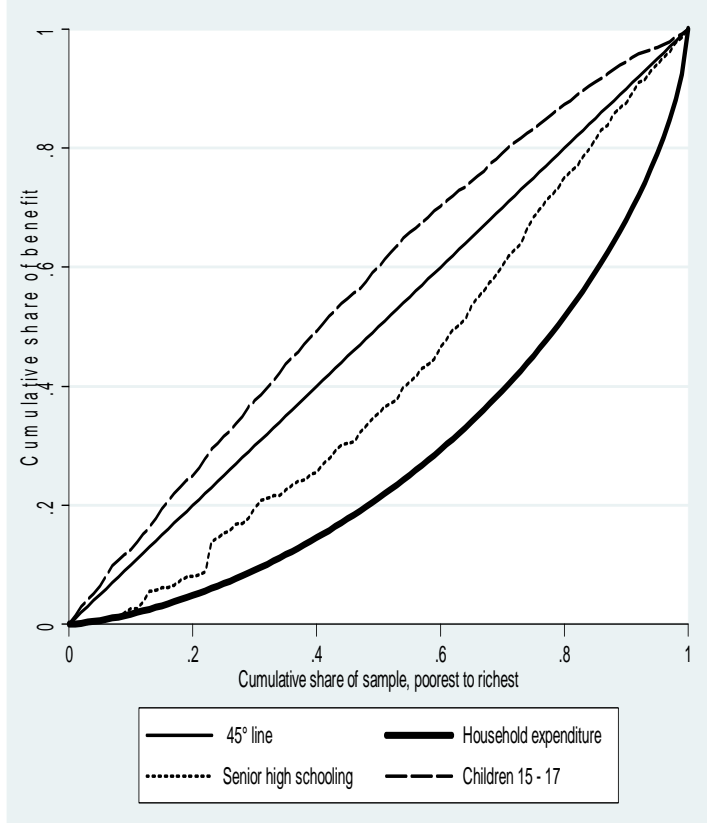

\section{Source: Own estimation based on GLSS 5 survey}


Figure 2 (continued)

(e) Tertiary schooling, 2005/2006

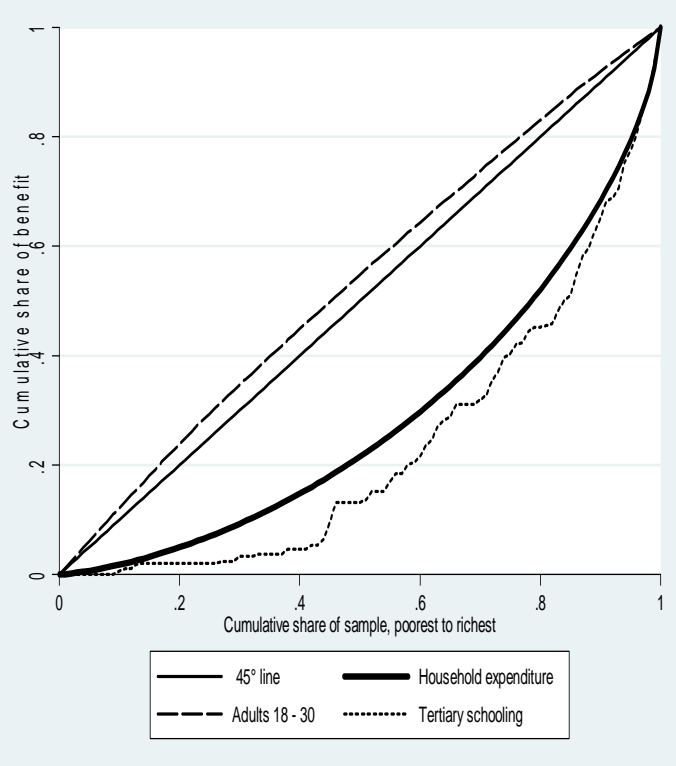

(g) All public schools, 2005/06

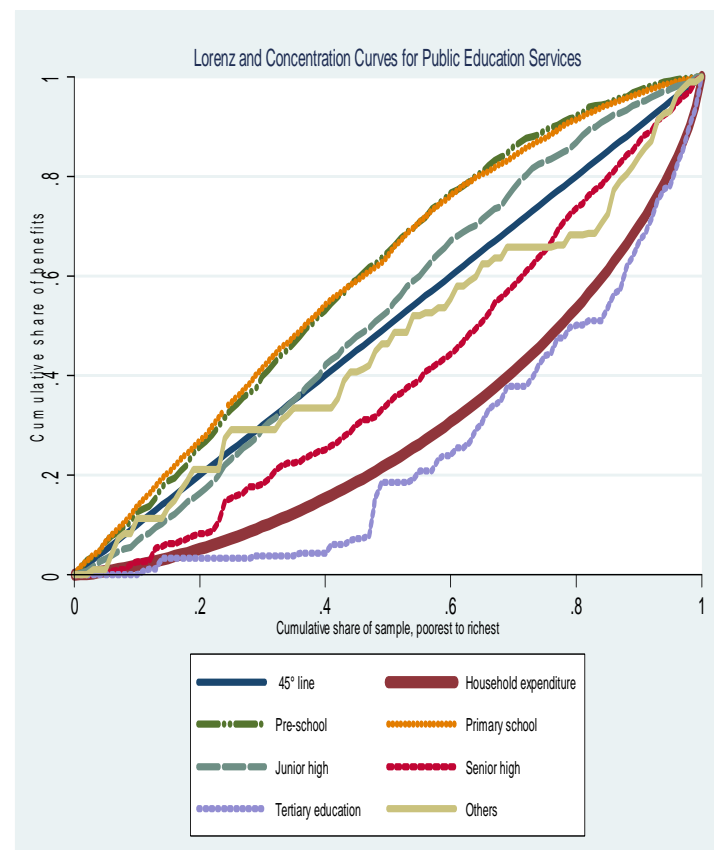

(f) All public schools, 2005/06

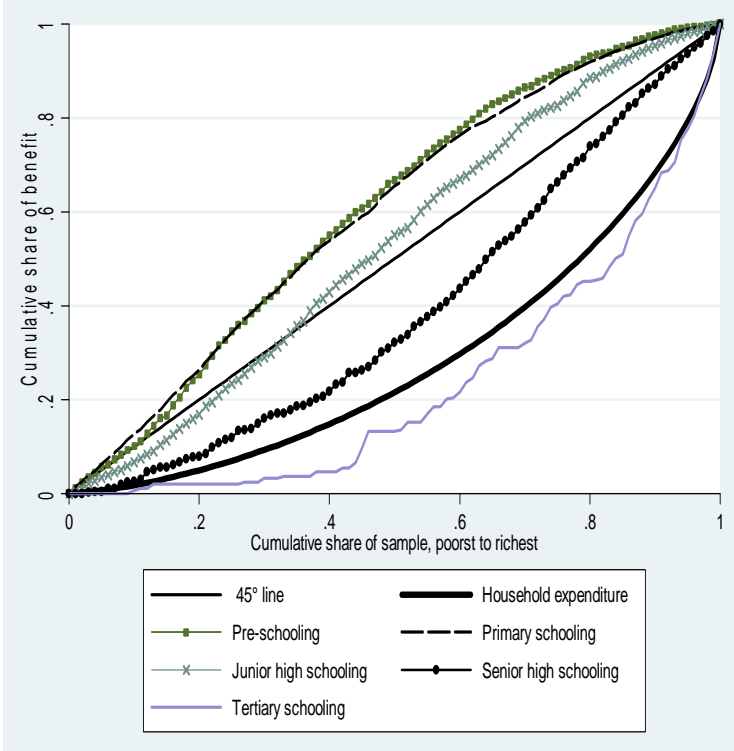

(h) All public schools, 2005/06

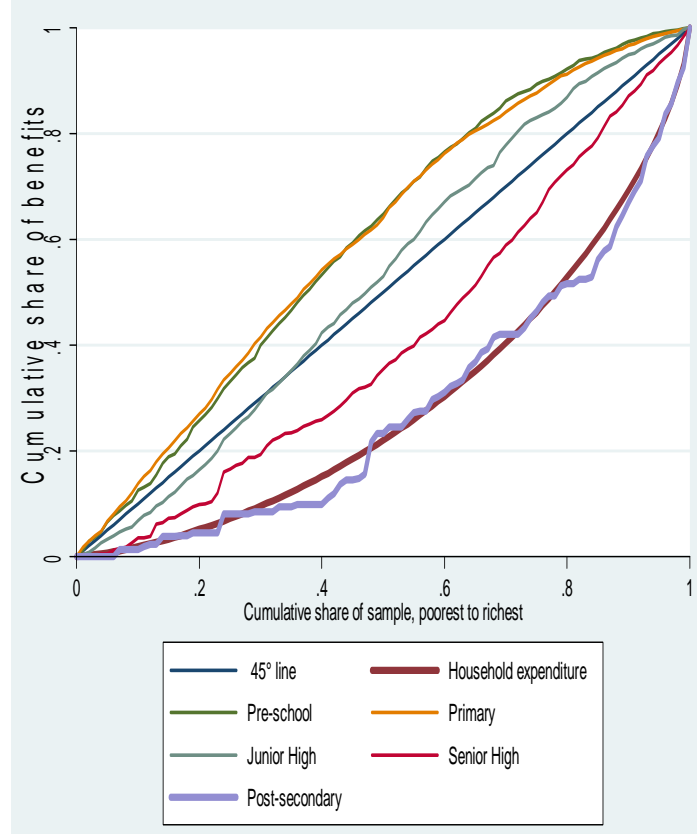

Note: "Others" include teacher and vocational training. Tertiary includes universities and polytechnics; Post-secondary includes tertiary and teacher education.

Source: Own estimation based on GLSS5 data 
Figure 3: Concentration curves for CV, standard, and uniform methods, 2005/06
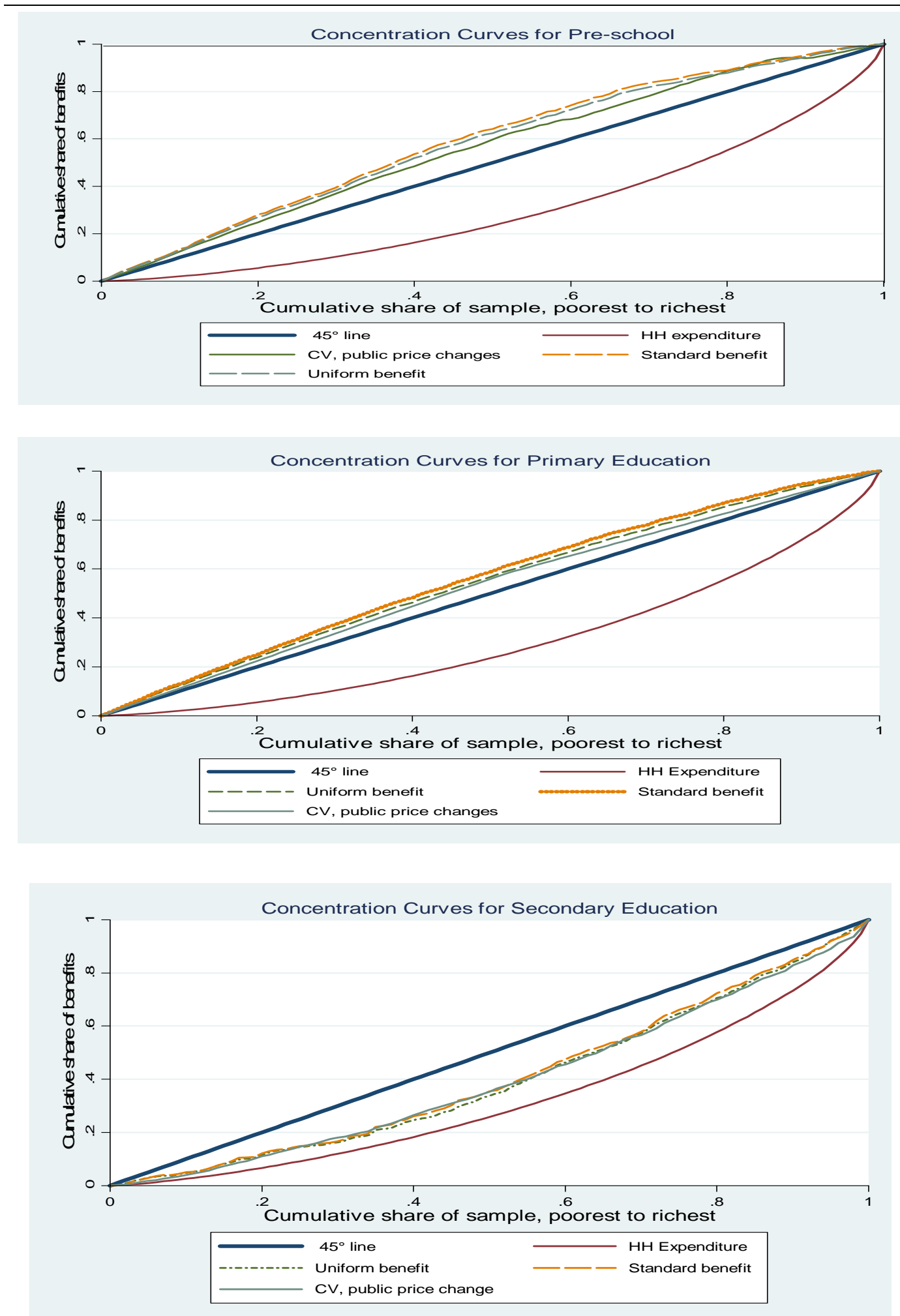

\section{Source: Own estimation based on GLSS 5 survey}

